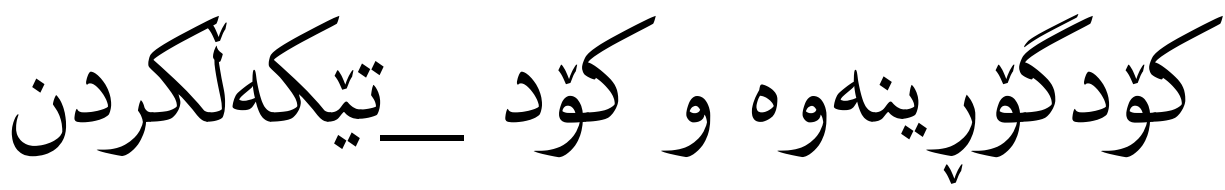

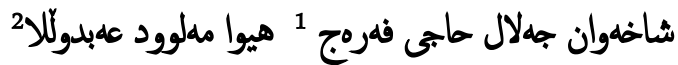

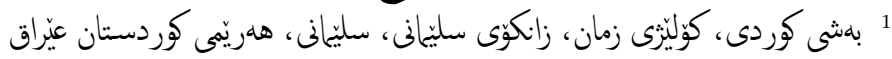

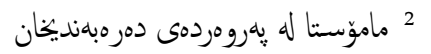

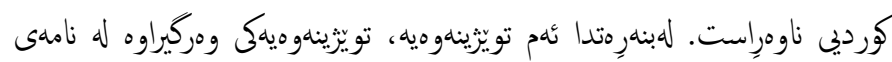

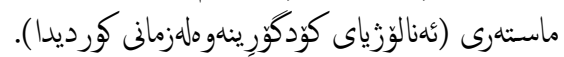

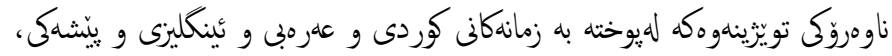

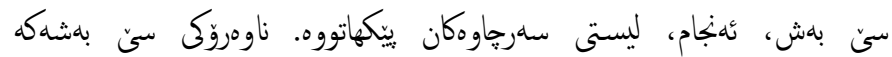

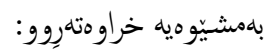

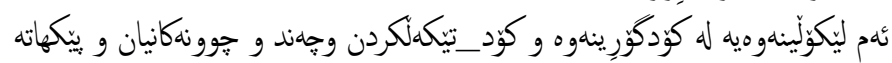

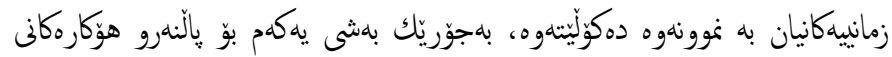

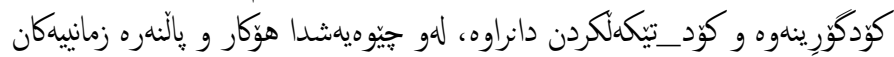

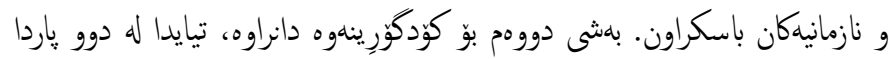

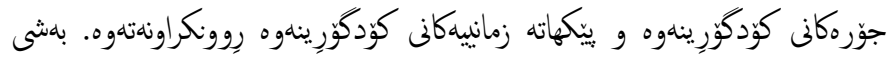

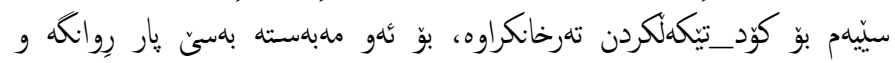

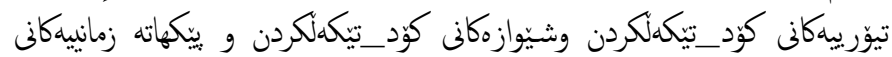

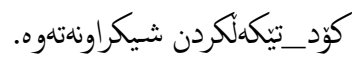

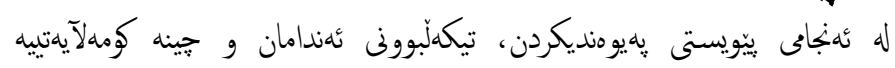

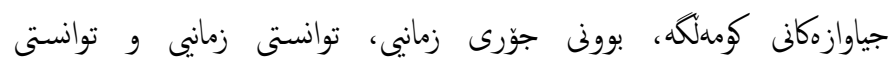

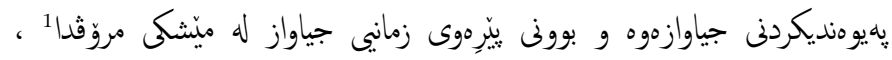

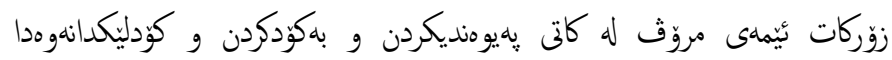

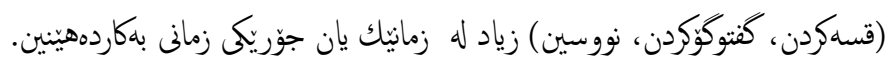

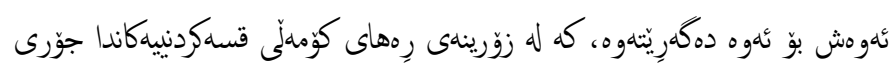

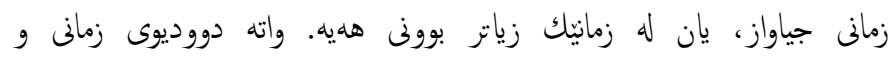

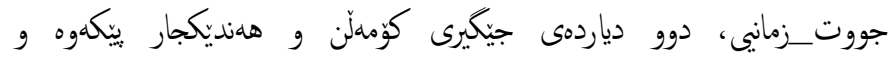

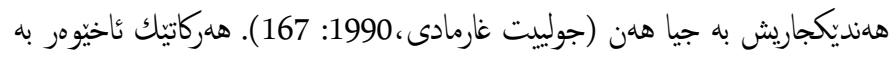

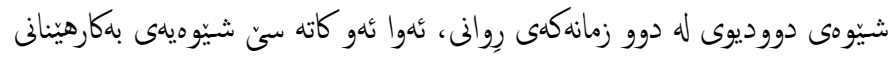

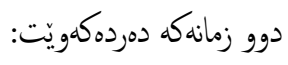

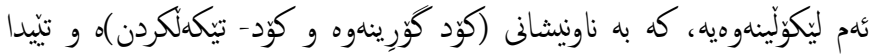

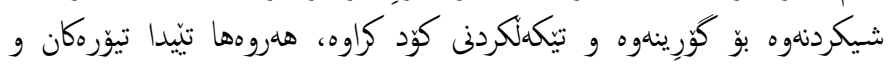

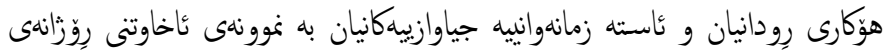

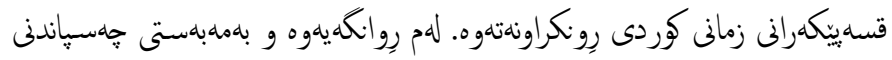

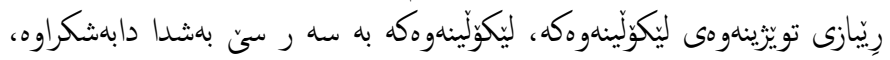
كه بريتين له:

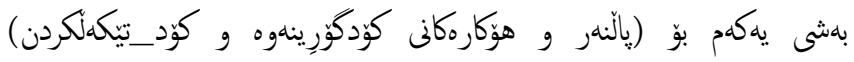

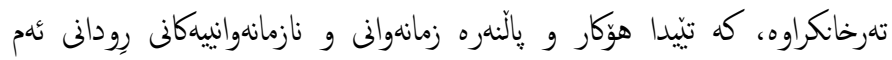

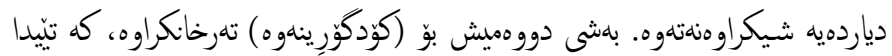

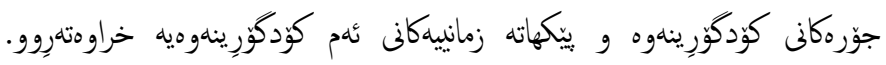

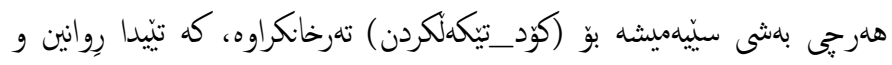

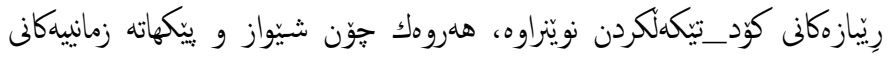

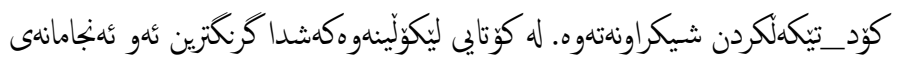

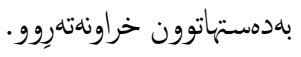

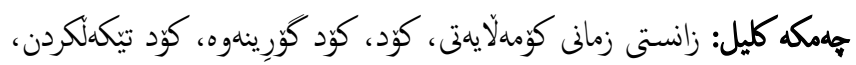

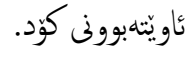

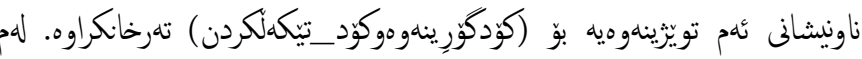

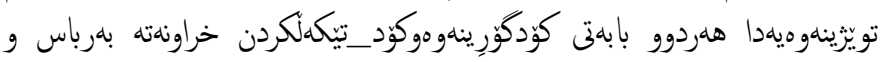

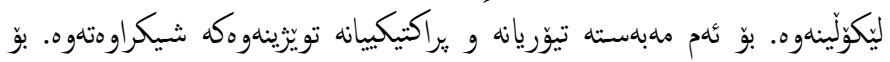

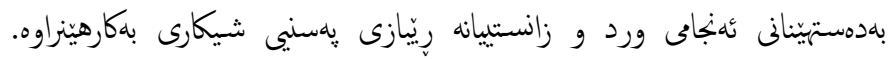

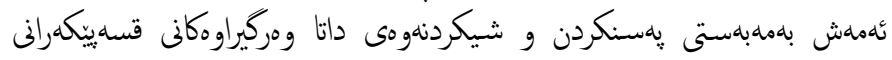




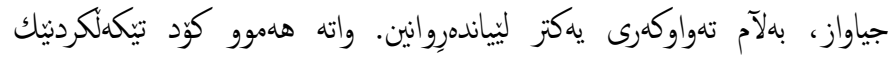

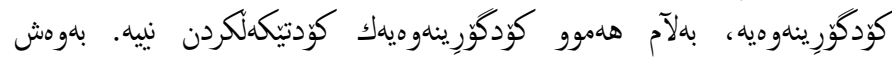

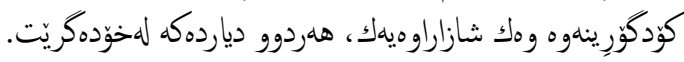

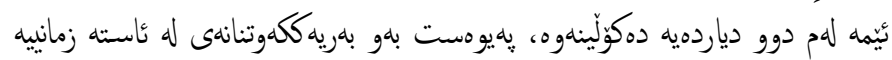

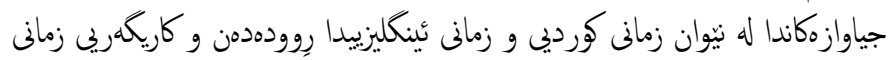

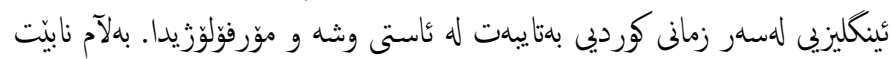

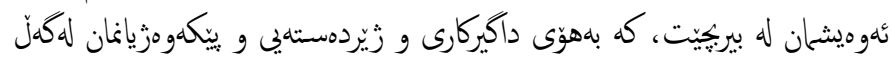

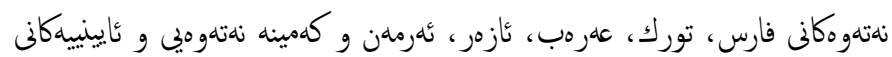

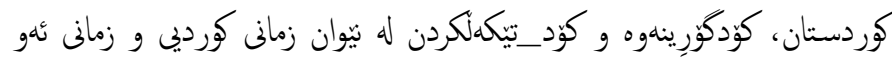

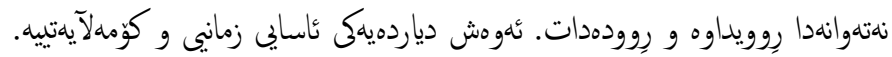

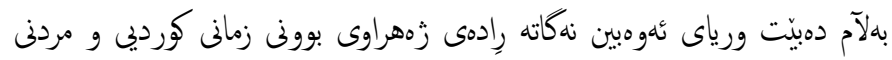

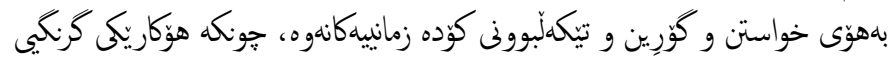

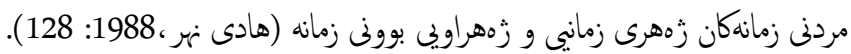

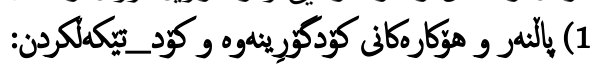

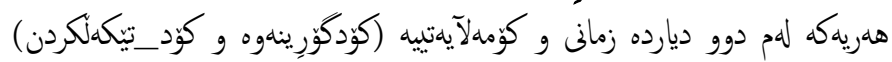

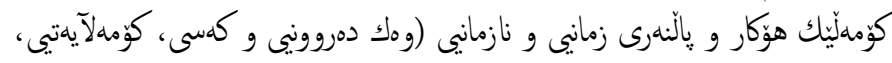

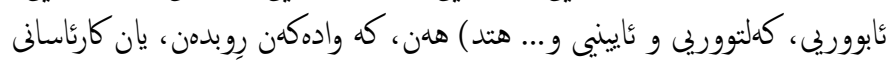

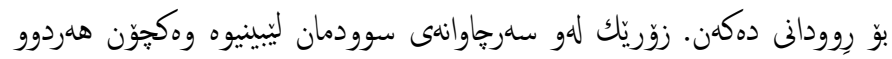

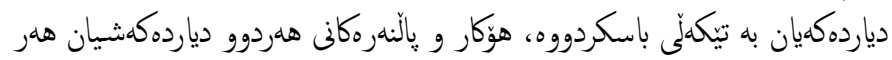

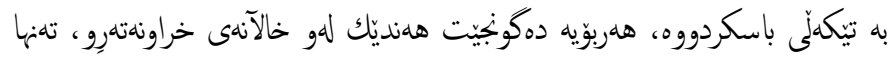

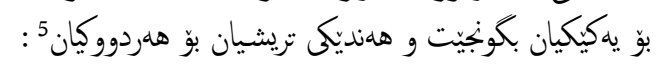

1/1 هؤكار و بالنهره زمانيبهان:

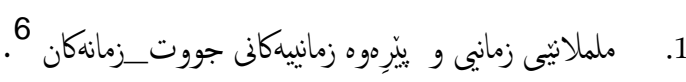

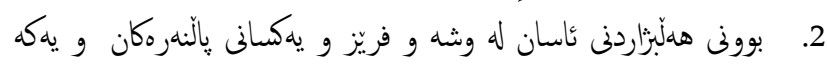

$$
\text { فهرهن:كييةكان. }
$$

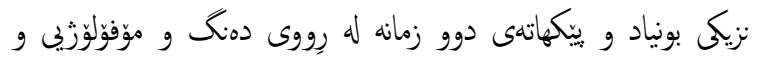

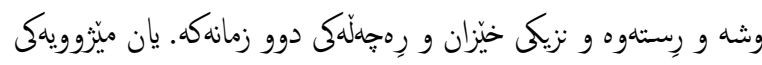
دريّز له بهيوهندى نيوان دوو زمان.

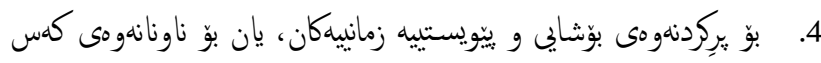
و شتنهكان و رِووداوهكان و كارهكان و دياردمكان.

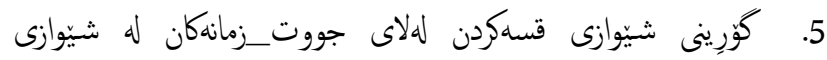

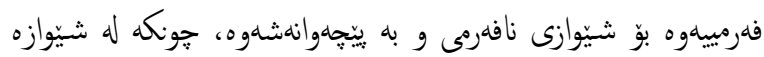

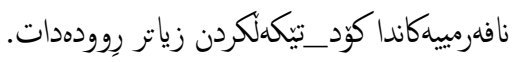

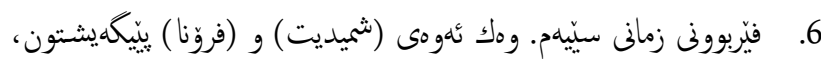

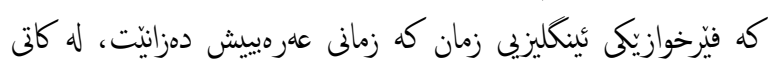

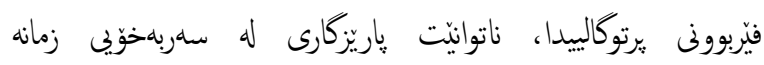

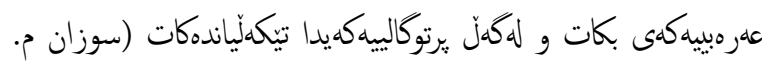

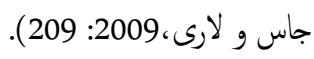

1. له بارودؤخى جياوازدا زمانى جياواز بهكاردههينين، وهك بهكارهينانى

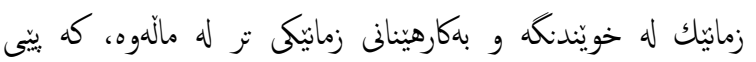

$$
\text { دمكوتريّت دووديويى زمانيى (Diglossia). }
$$

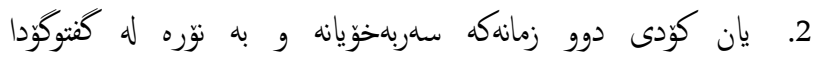

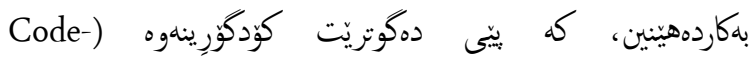
.(Switching

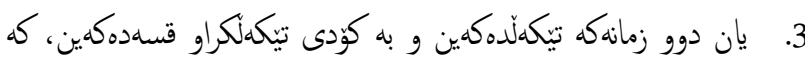

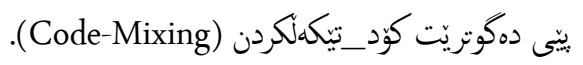

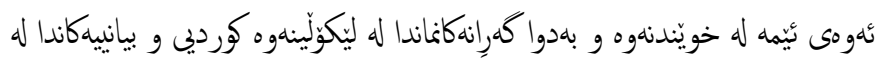

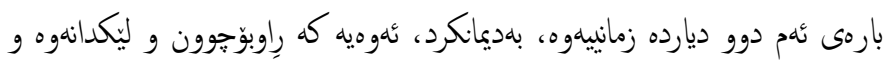

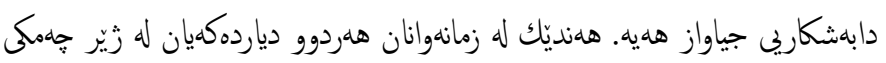

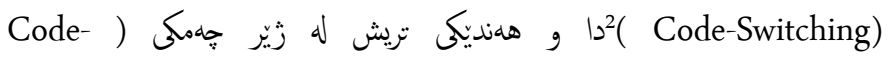

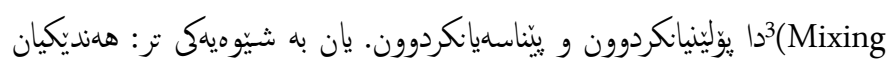

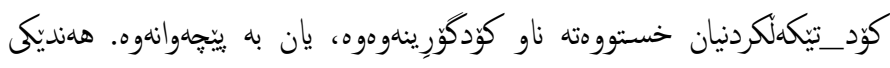

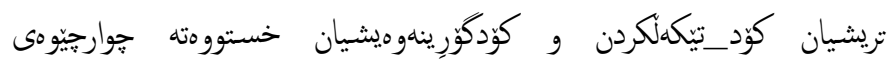

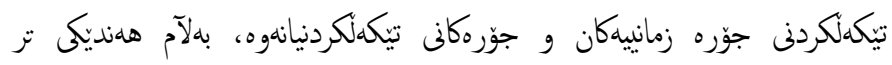

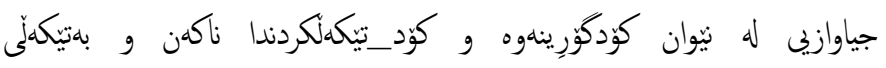

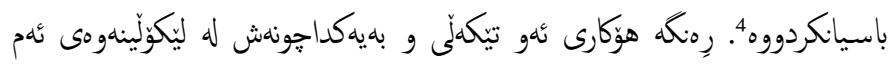

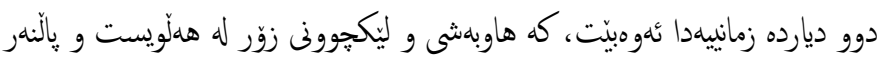

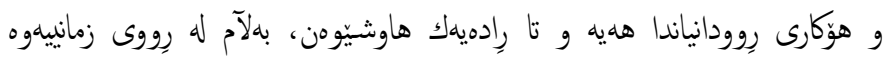

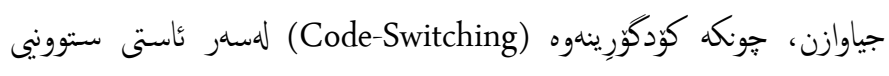

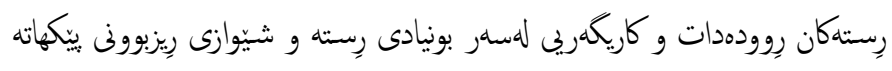

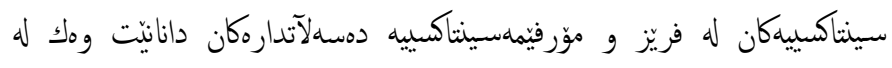

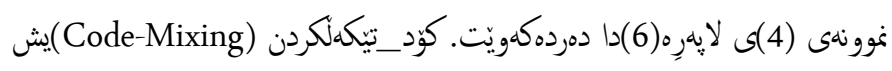

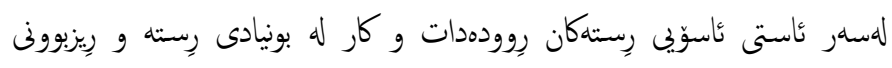

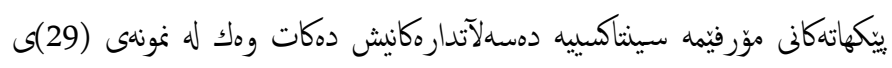

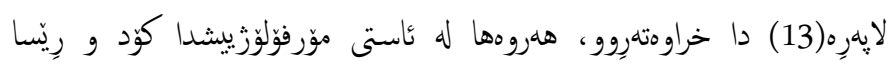

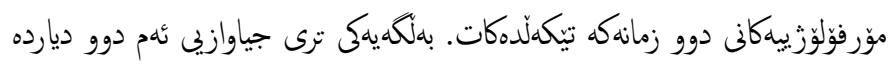

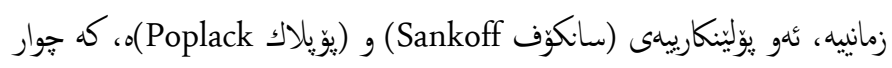

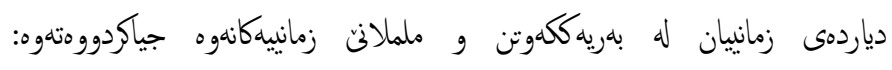

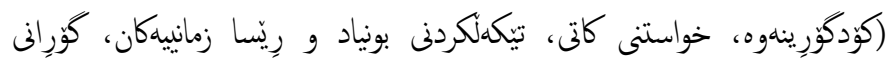

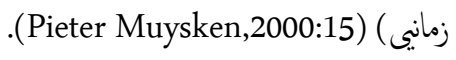

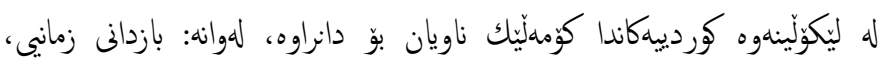

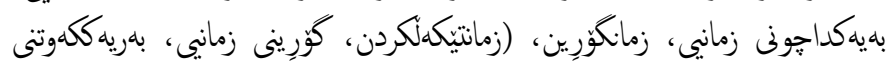

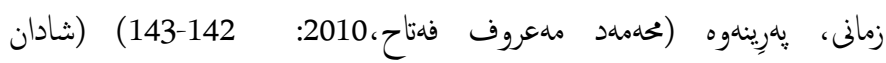

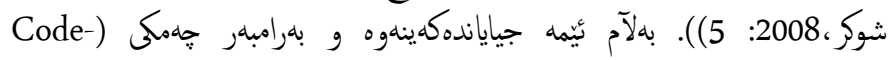

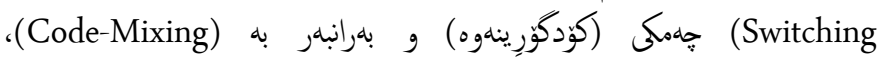

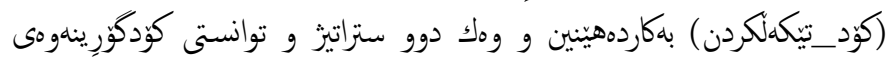




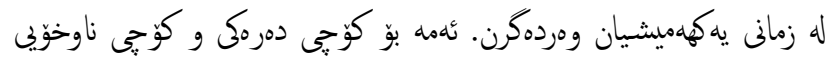

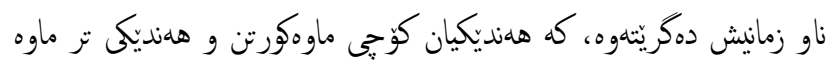

دريزّن (110-Carmen Llamas,2007: 109.

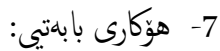

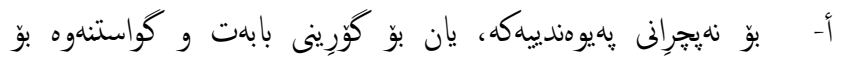

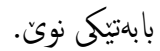

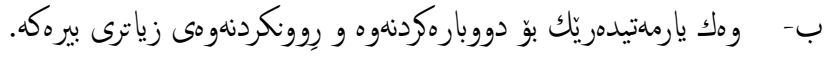

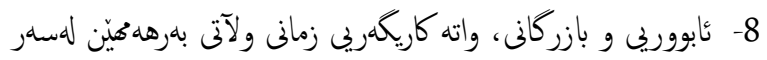

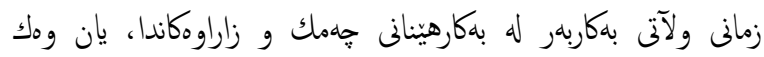

دروستكردنى زمانه يِيجين و كويولة لكان.

\section{: Code-Switching كؤوكورينهوه}

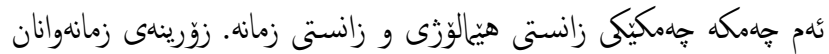

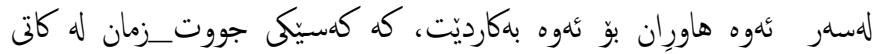

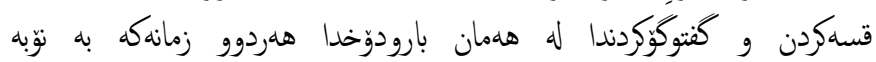

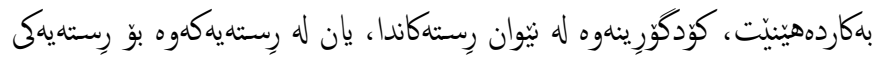

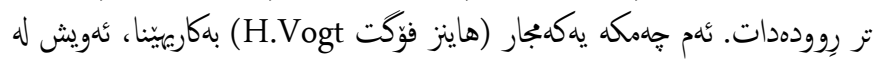

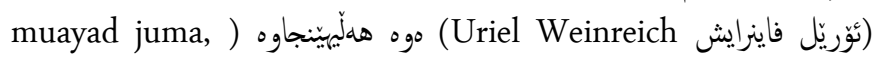

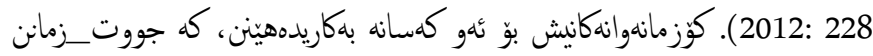

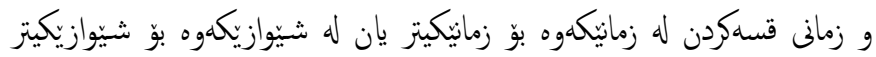

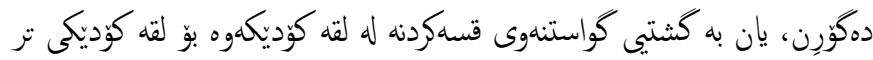

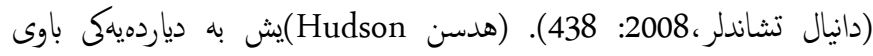

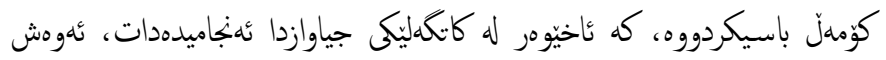

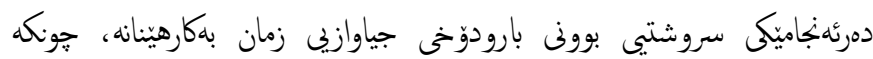

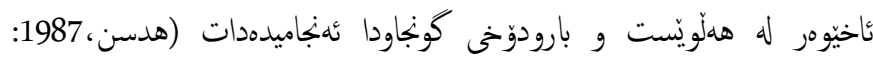

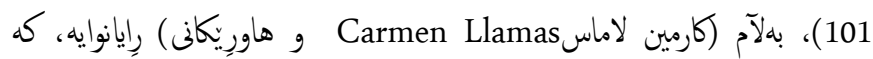

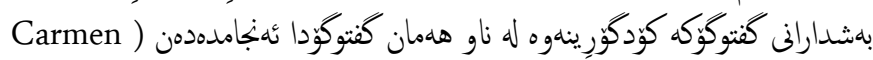
208

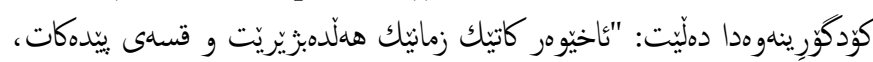

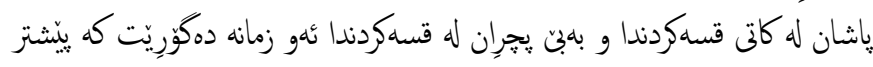

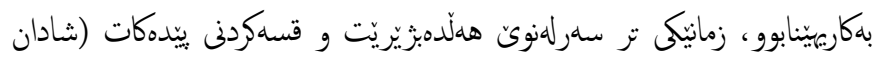

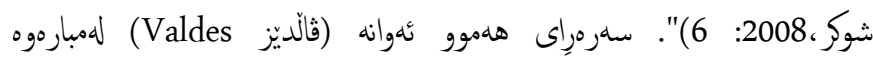

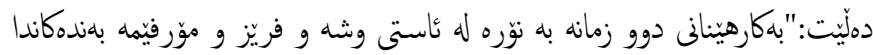

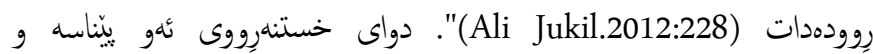

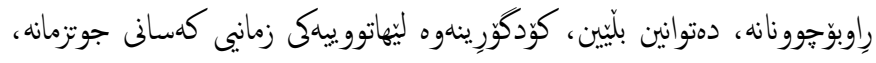

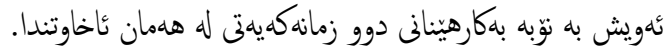

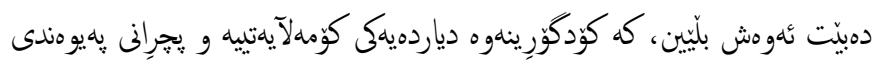

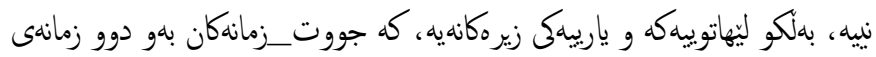

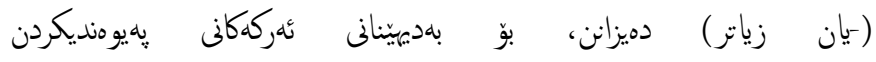

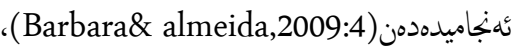

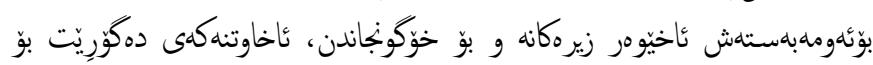

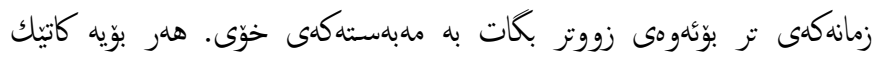

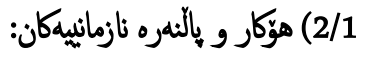

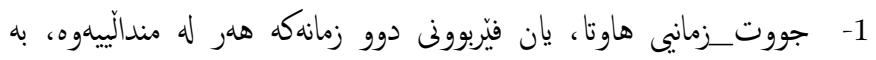

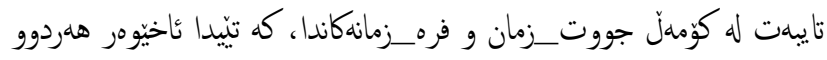

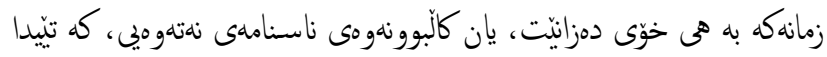

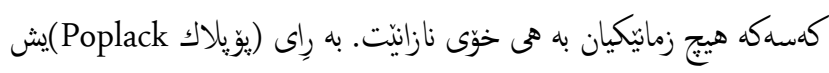

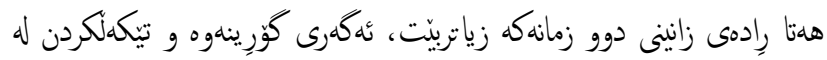

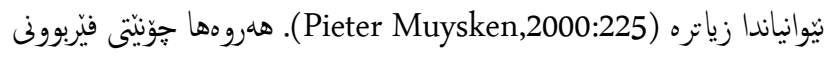

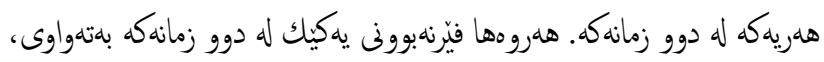
يان كمسيكه نيوه جووت_زمانه و خوّى به خاوهنى هيج زمانيكيان نازانيت.

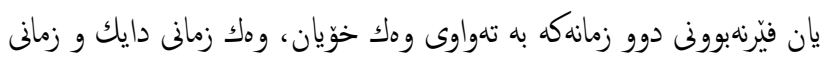

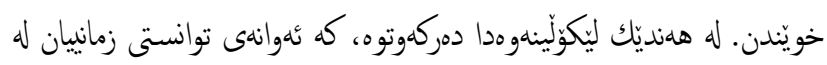

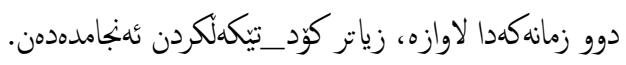

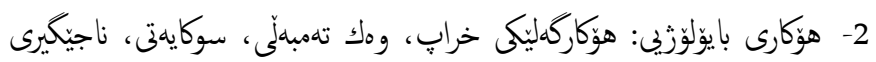

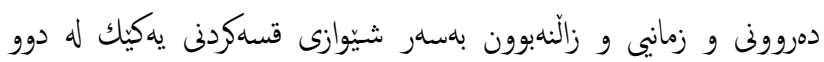

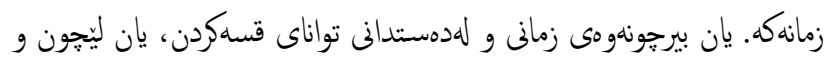
لـدمستدانى زمانيى. 3- - هوَّارى دمروونيى:

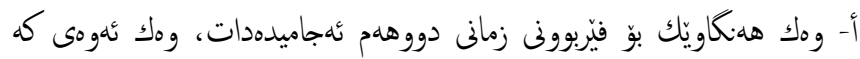

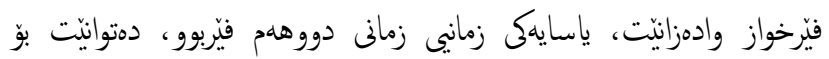
هلموو هلوّويّست و دوّخيَكى زمانى بهكاريبينينيت.

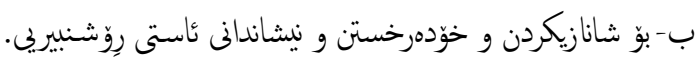

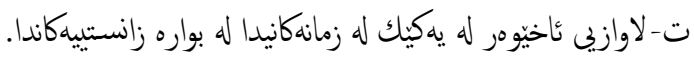

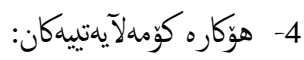

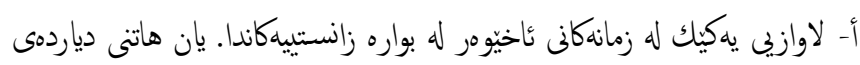

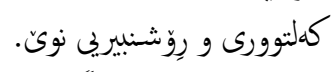

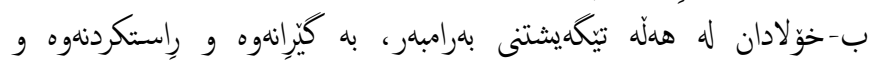

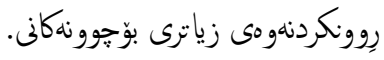

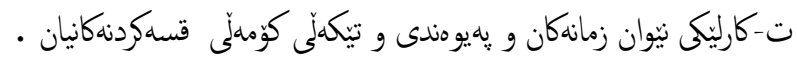

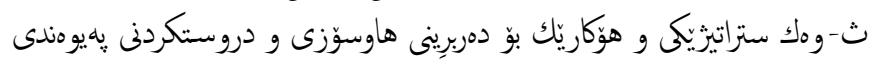

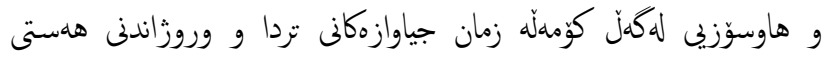

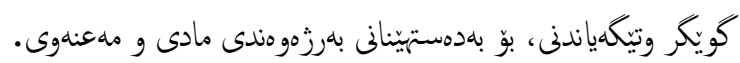

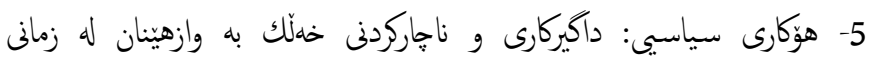

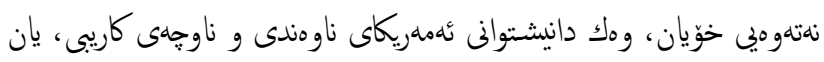

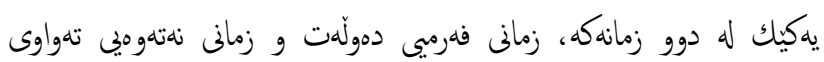

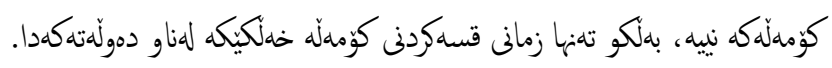

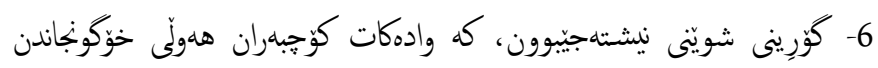

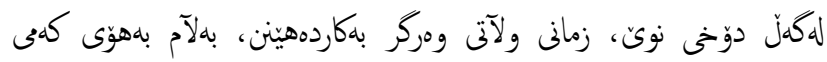

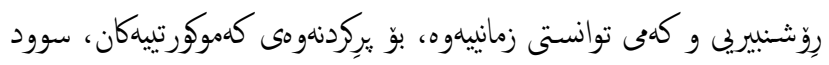




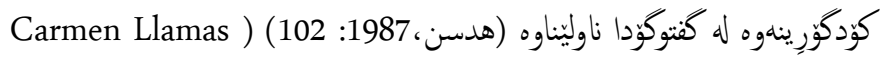
.(\& Ltd,2007: 208

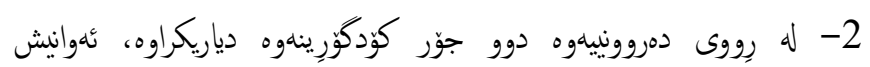

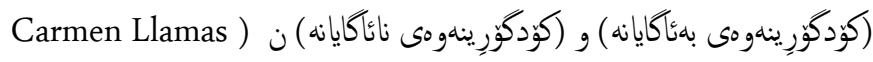

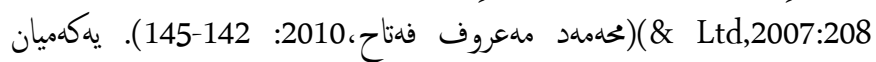

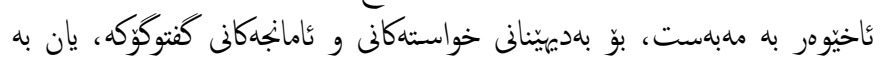

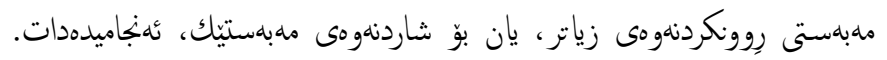

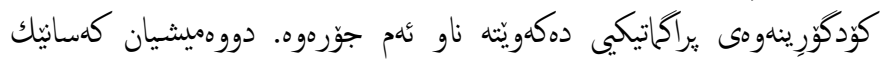

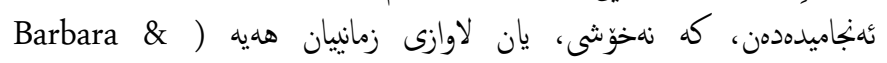
7

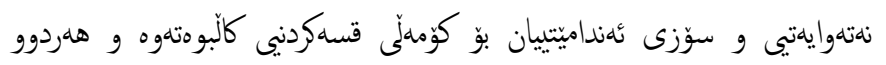
زمانهك به هي خوّيان دمزانن.

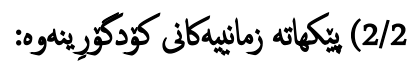

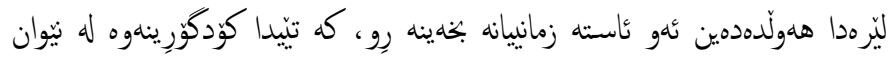

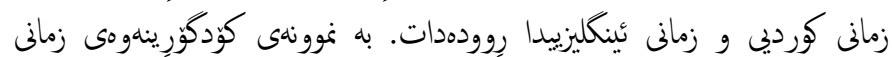

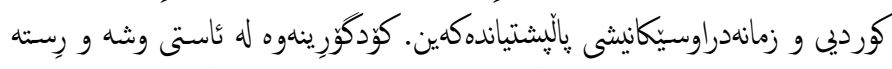

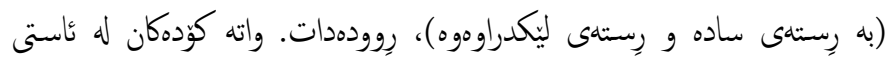

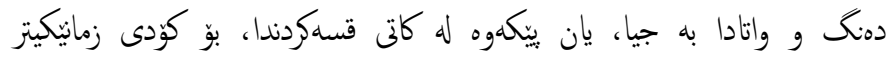
دمكورِدرينّهوه.

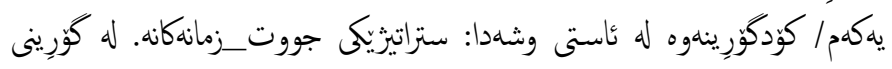

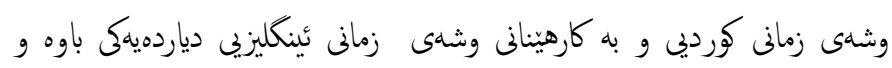

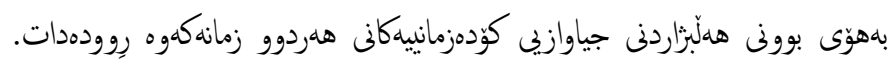

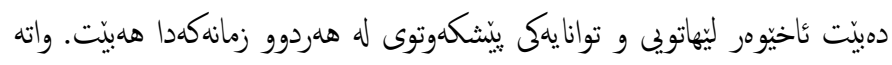

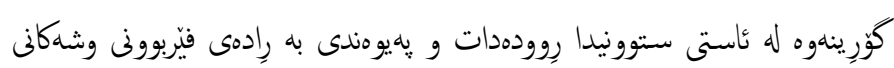

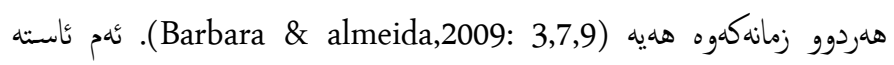

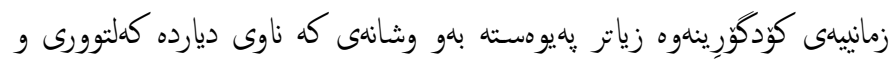

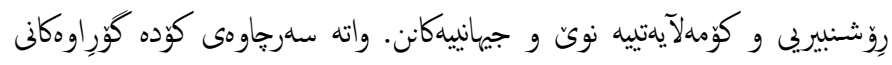

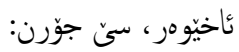

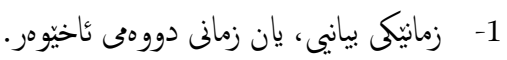

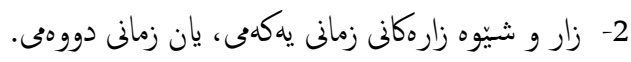

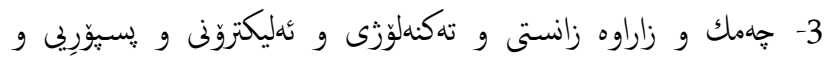

$$
\text { جيهانيهكانى تر. }
$$

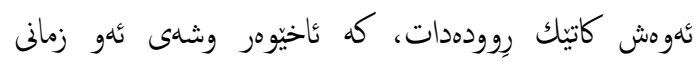

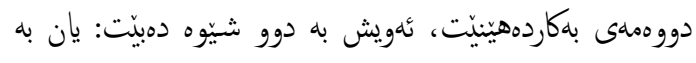

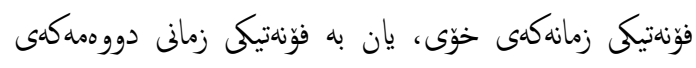

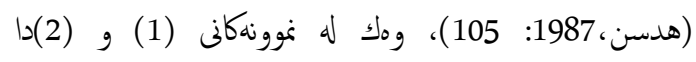

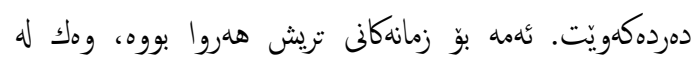

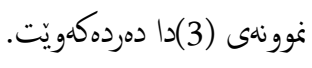

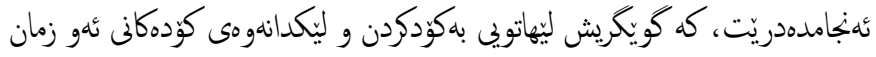

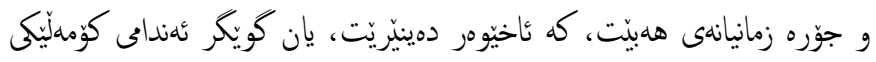

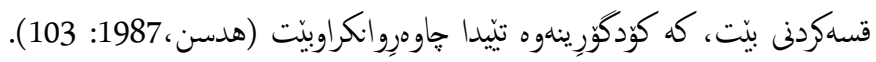

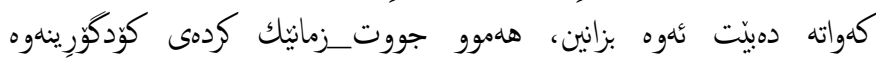

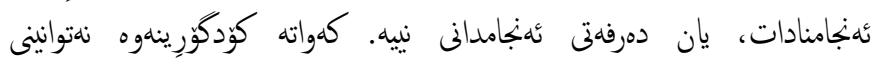

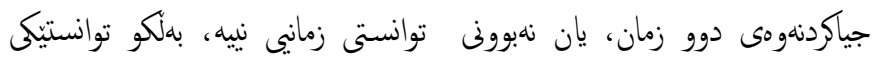

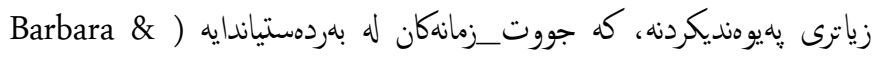
(almeida,2009: 8

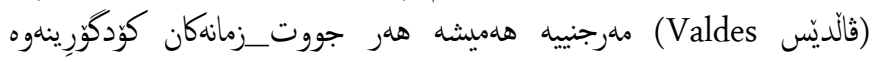

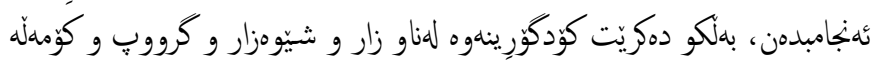

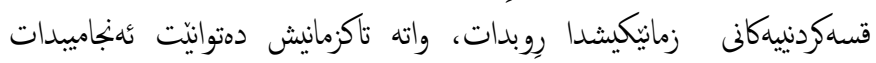
.(Barbara \& almeida,2009: 2) muayad juma,2012: 228)

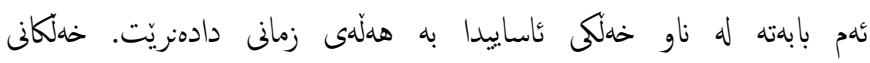

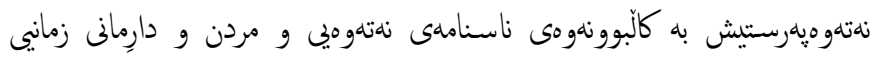

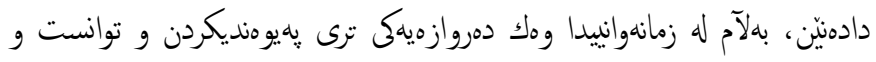

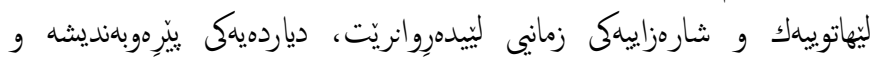

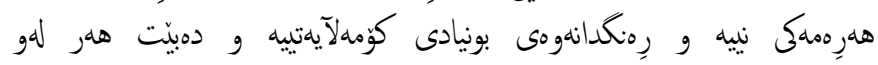

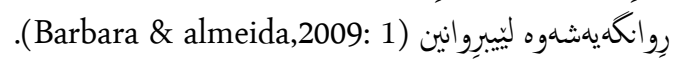

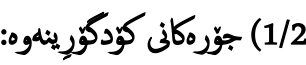

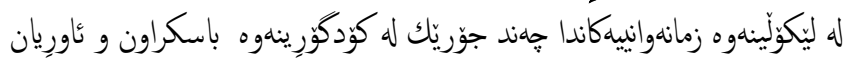

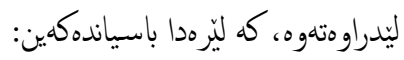

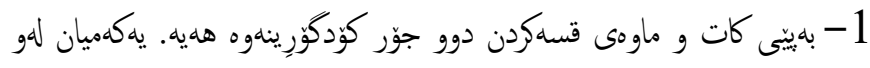

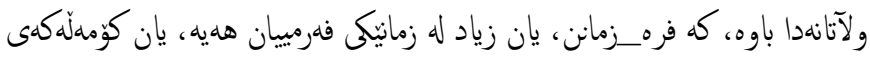

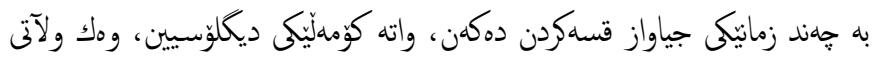

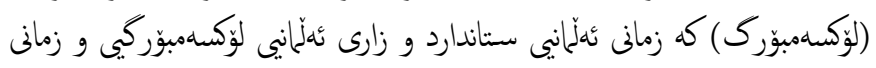

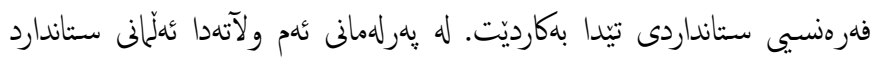

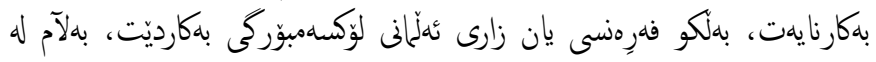

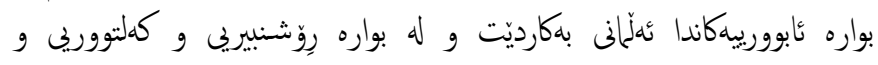

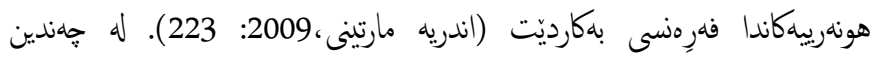

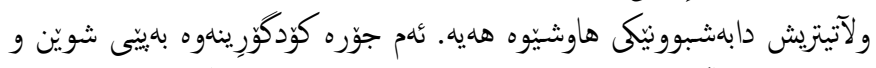

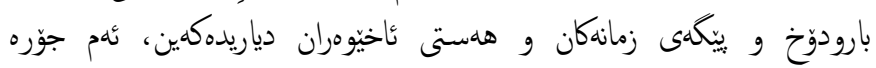

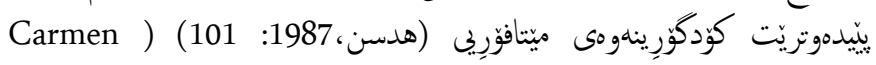
Barbara and (Llamas\& ...,2007: 208 (Almeida

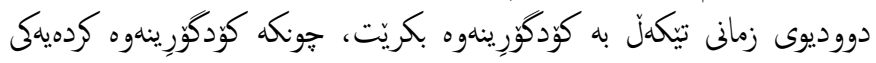

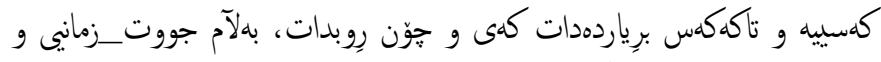

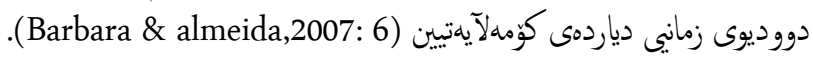

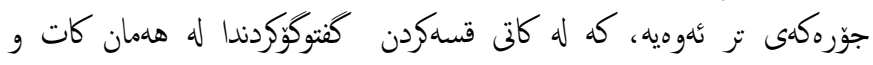

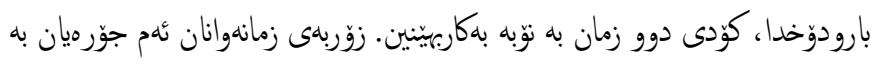

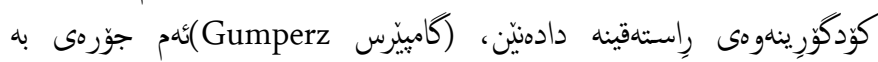




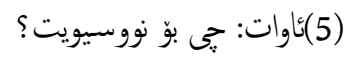

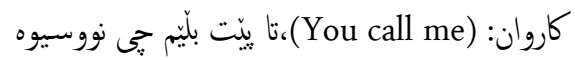

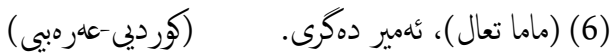

3) كود_تيككلكردن:Code-Mixing

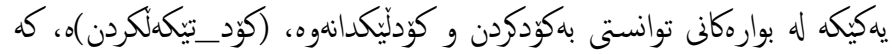

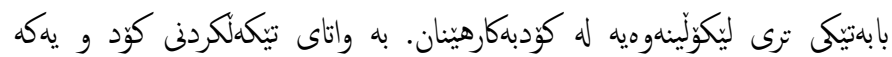

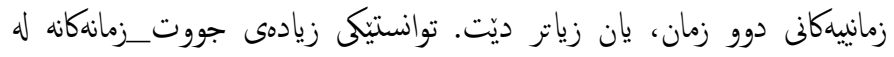

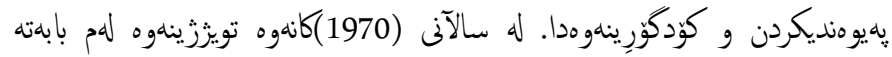

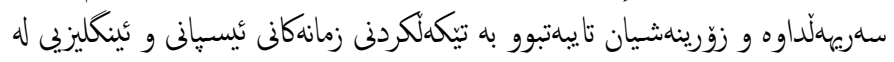

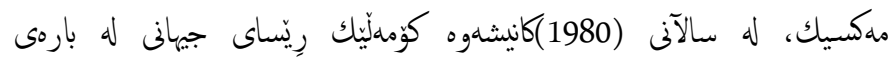

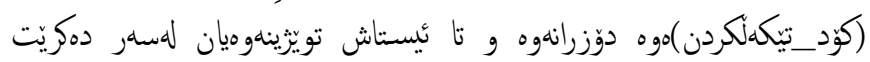

(Pieter Muysken,2000:12).

له بارمى ناساندن و يبيّاسهكردنيهوه، به تيكهلكردنى كؤده زمانييهكانى دوو زمان له

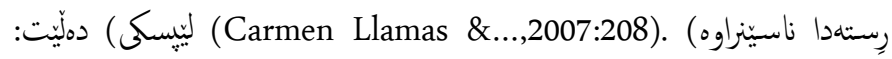

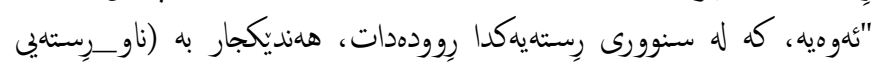

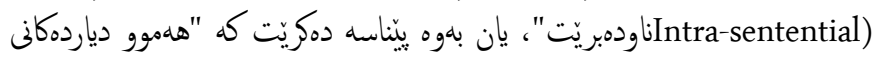

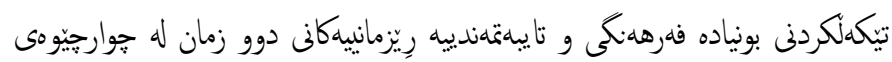

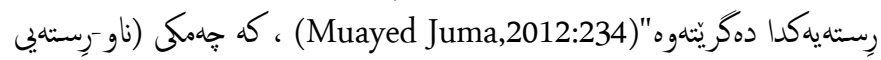
Intra-sentential)

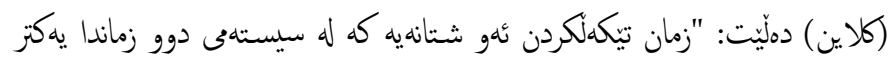

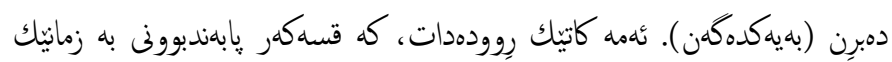

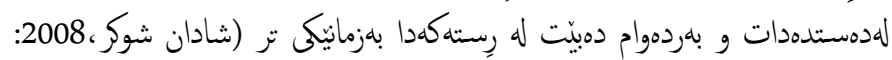

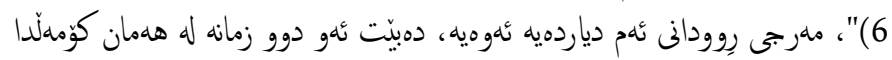

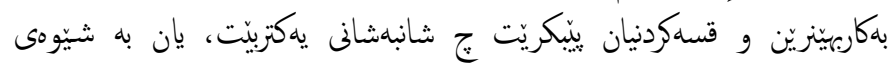

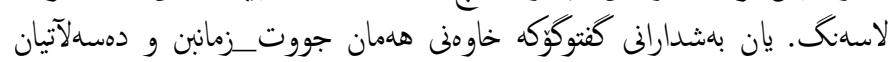

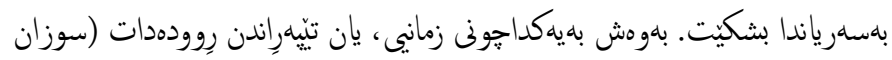

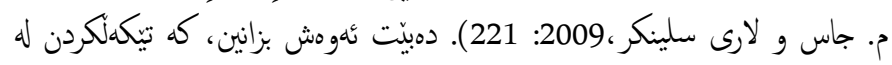

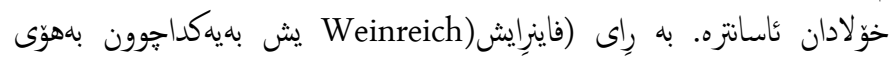

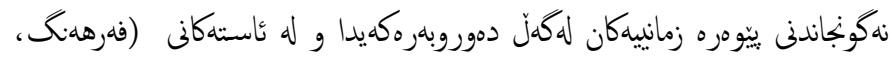

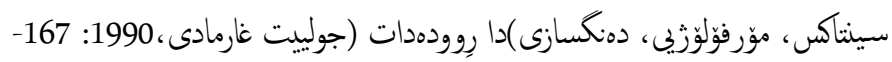

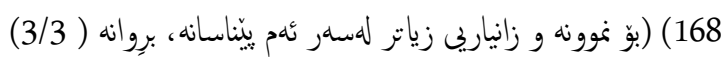

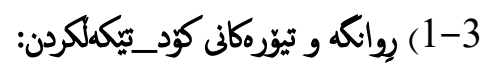

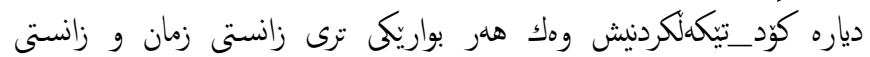

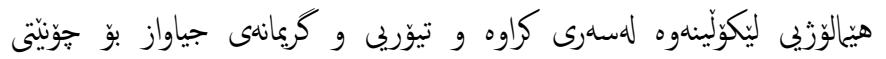

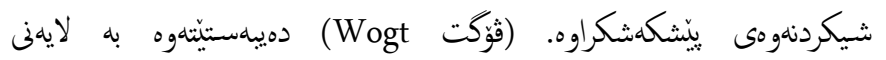

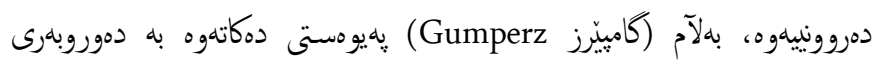

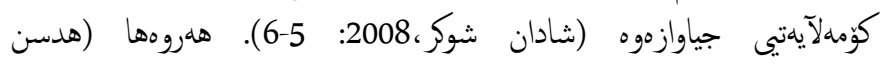

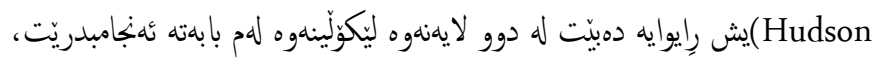

كه:
1 ) أنامانج كورِيكى نهكتيثه .

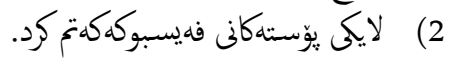

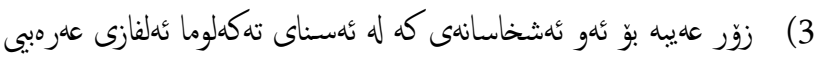

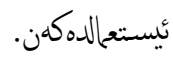

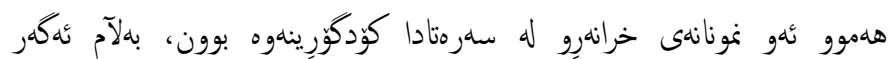

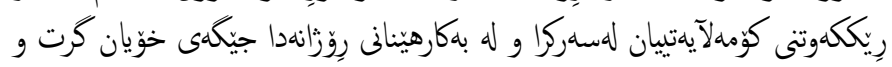

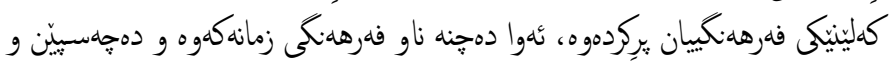

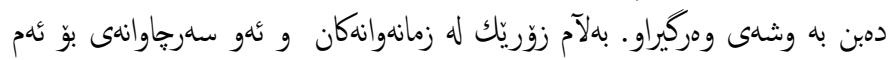

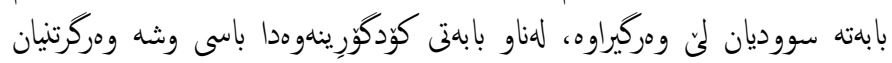

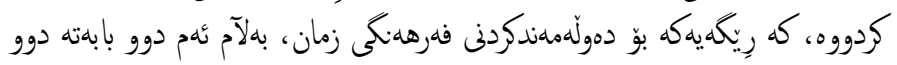

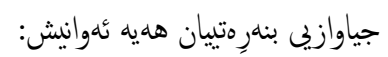

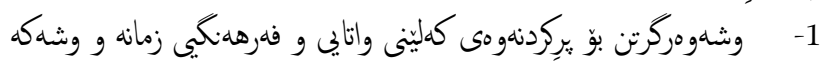

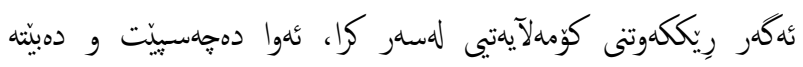

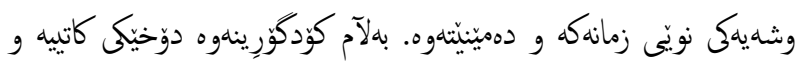

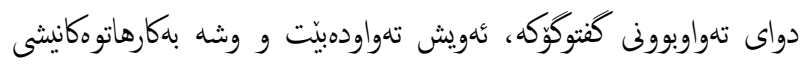

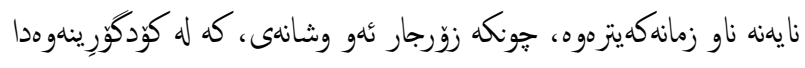

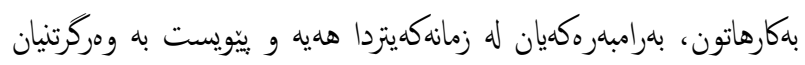
ناكات.

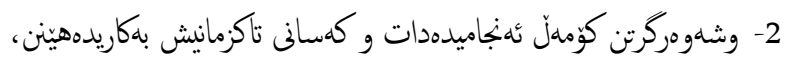

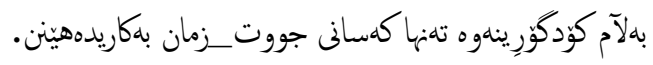

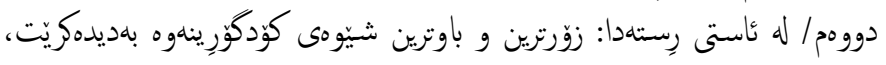

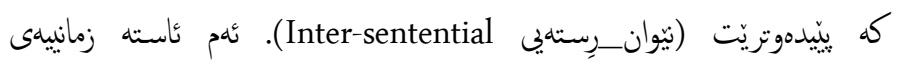

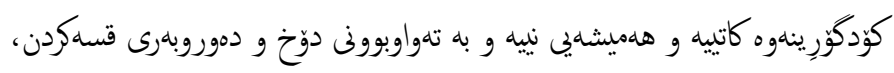

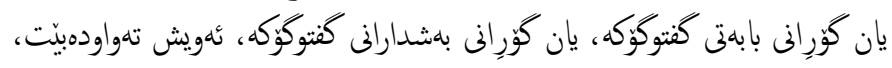

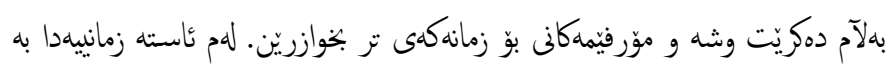

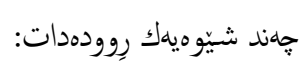

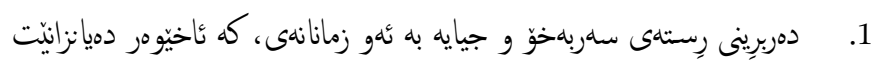

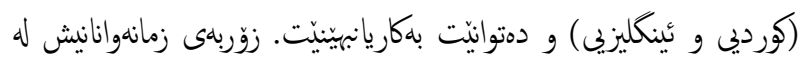

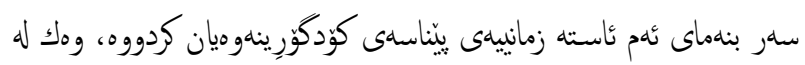

$$
\begin{aligned}
& \text { نموونهى (4) دمردمكهويت. } \\
& \text { ماريا: سلآو، ندم كاتهت باش. }
\end{aligned}
$$

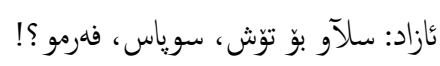

ماريا: Where is Sulaimani Palace?

: : كul Sulaimani Palace locates in the Salim street

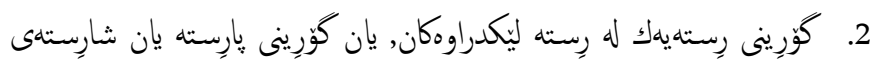

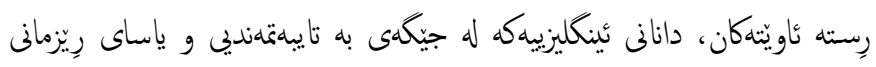

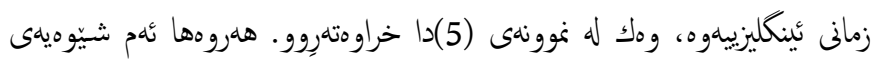

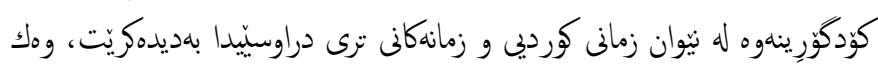

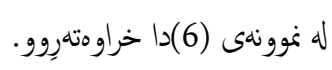


بالآدمتى يوّرتوكال بوه له دمرياوانيى و بازركانييدا. بهوهش دهريّت بوتريت، كه

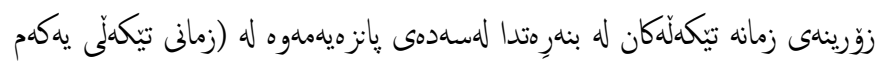
Proto-Sabir خوّيشى زمانيكى تيكةل بووه.

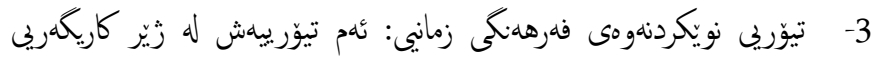

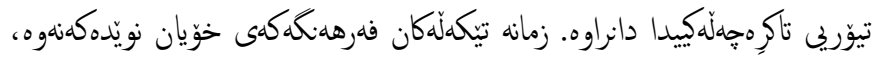

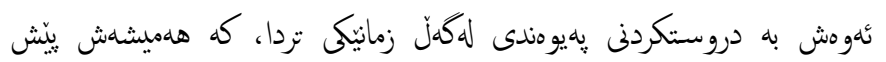

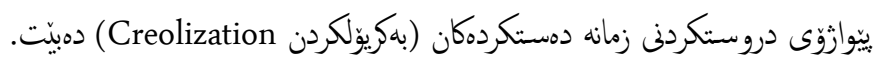

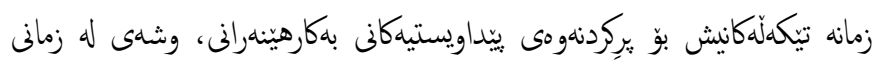

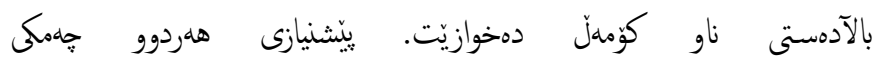
(Relexilication و دهات. (Supralexilication)

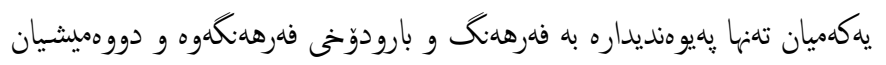

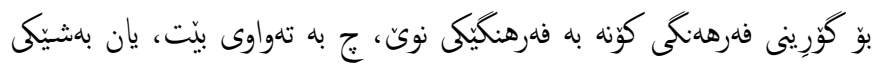

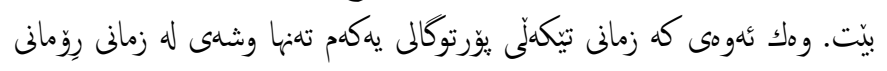

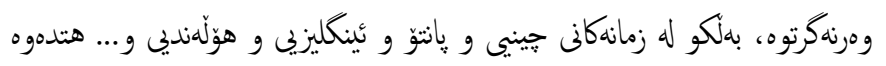
وهريكرتون.

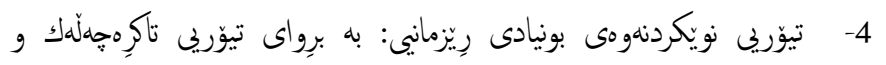

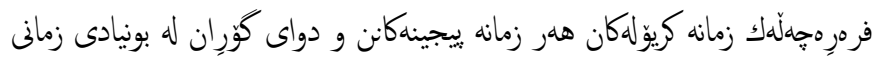

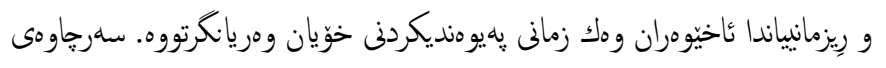
ثنهو كورِان و نويّيوونهوهيهش فره لايهنه.

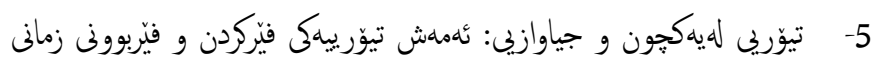

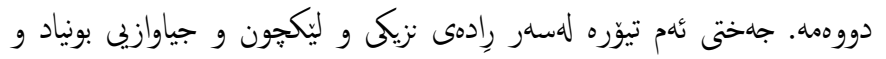

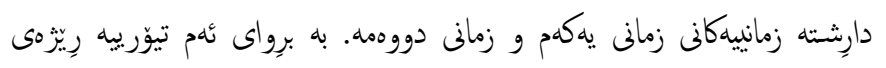

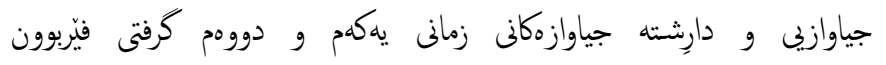

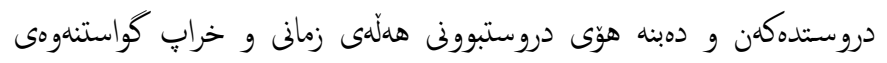

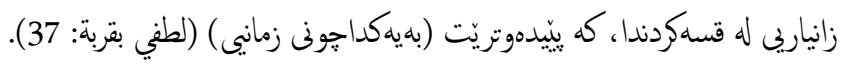

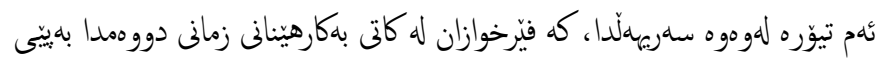

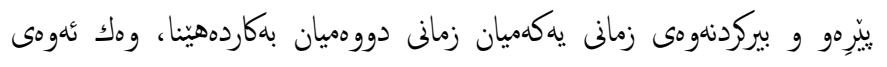

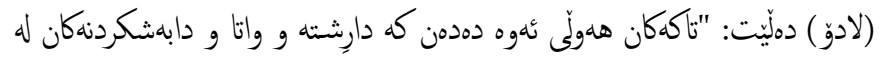

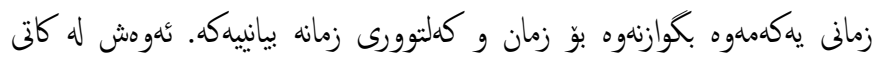

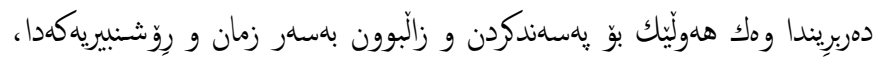

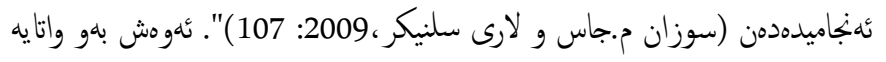
ديّت، ئاخيوهر به كهلتوورى زمانيك بيردهاتهوه، بلآلآ به زمانيكيتر قسهكودن

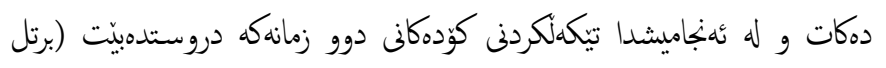

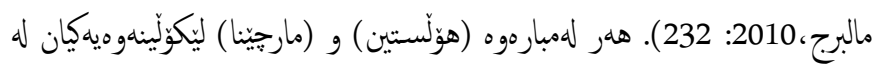

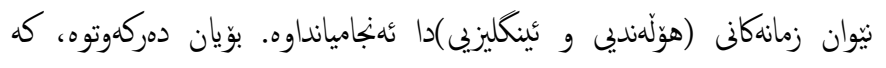

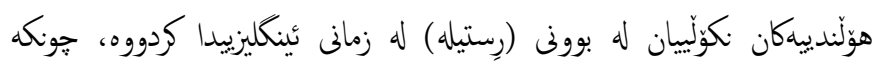

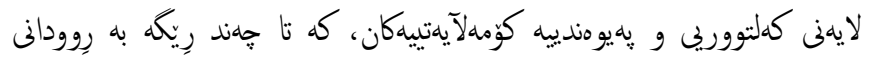

لايهنى بير و دمروونى مروّق و ئاوهزيان (هدسن، دمن 1987: 104-105).

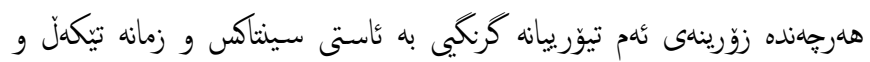

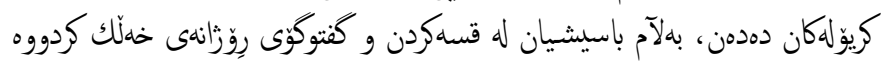

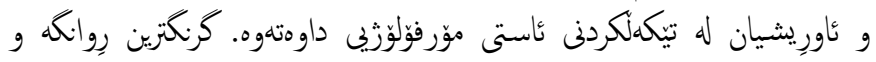

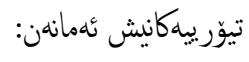

1-1/3 ِيوانكه زمانيهكان:

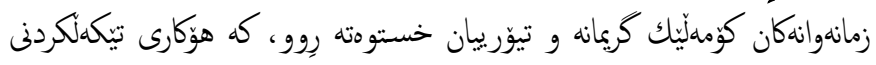

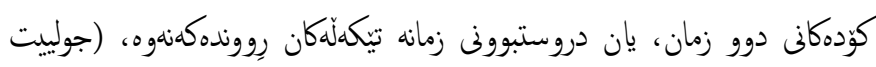

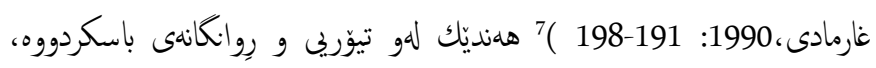
ل

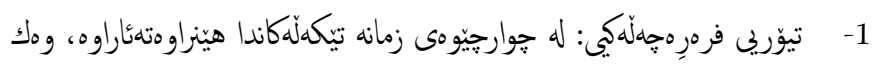

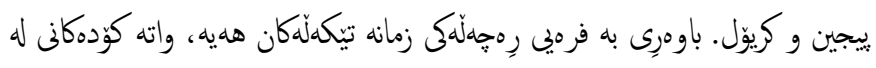

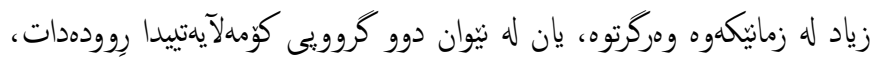

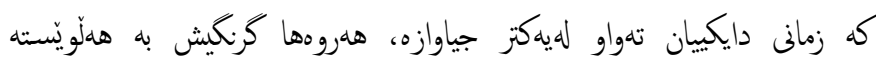
زمانييهكان و بونيادى زمانيى و مهرجه ميّزوويى و كوّملآيهتييهكانى كهشهكردنى زمانه

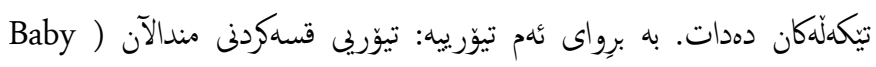

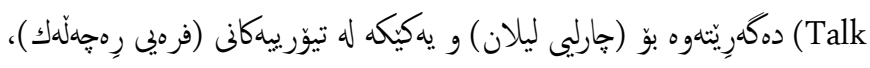

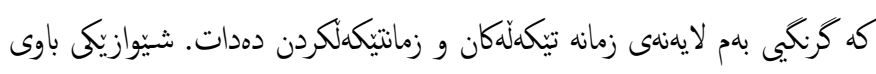

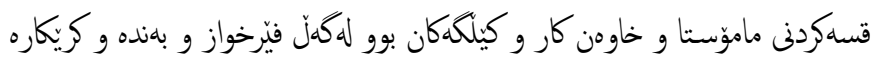

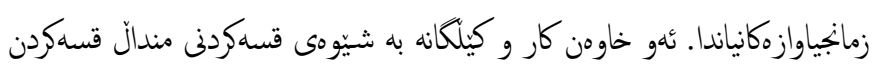

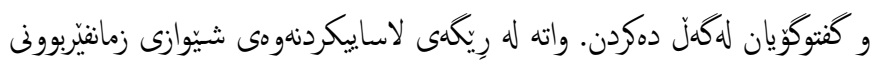

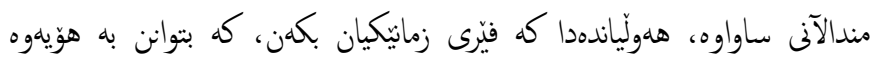

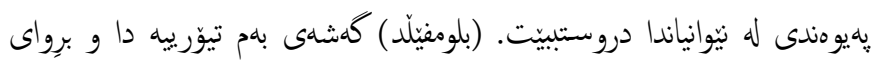

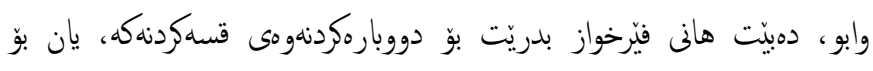

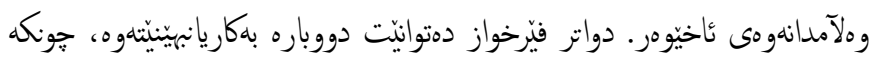

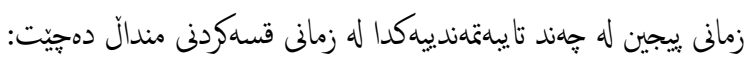
أ- ناوهزوكى وشهى زوّر بهرامبهر به زمارهيهك كهم له وشه. ب- يوّله وشهكانى له جاو زمانى ههراشهكاندا زوّر لاستيكيين.

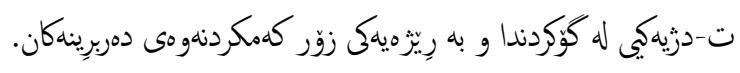

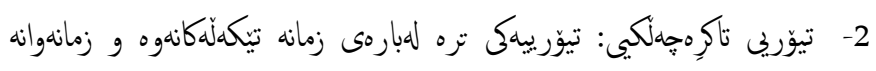

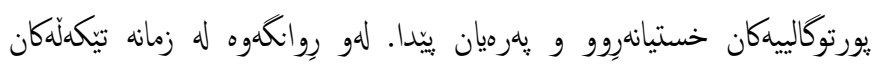

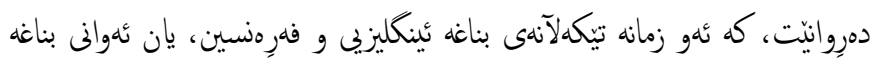

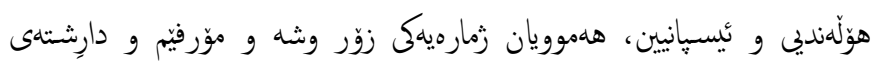

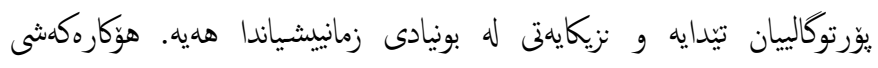




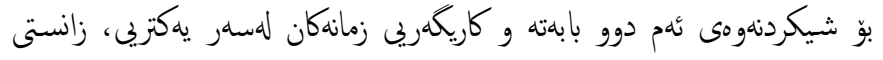

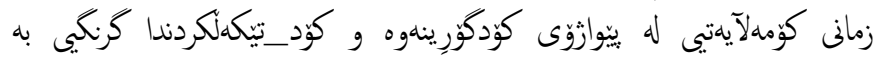

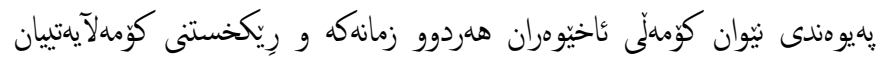

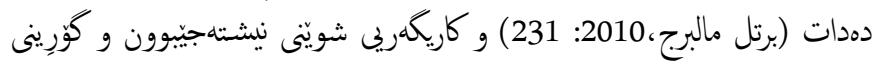
شوين (Carmen Llamas \&...., 2007: 110) دمدات.

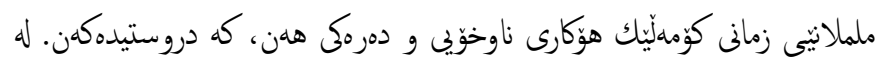

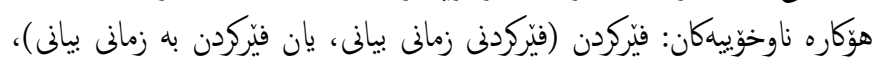

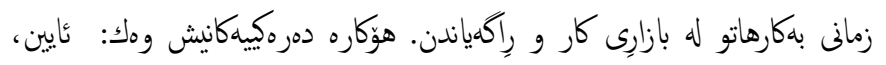

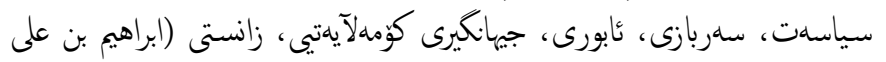

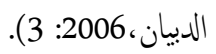

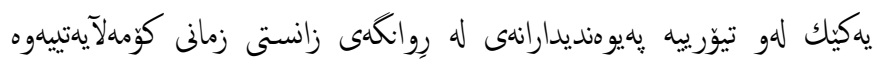

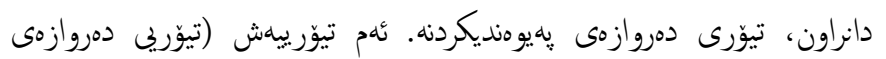

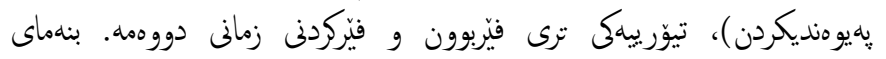

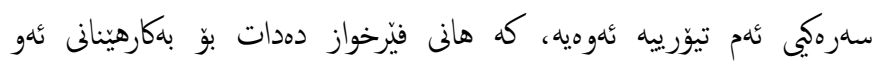

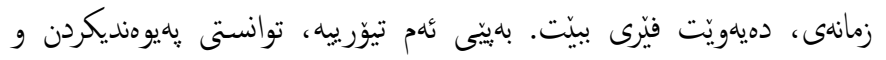

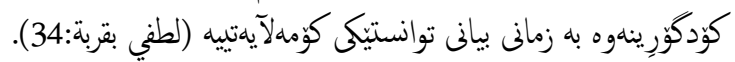

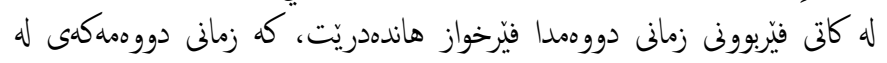

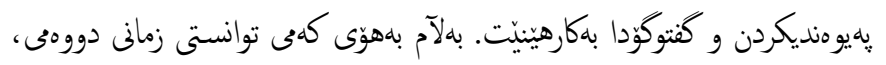

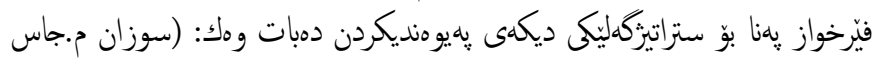
و لارى سلينكر، 2009:

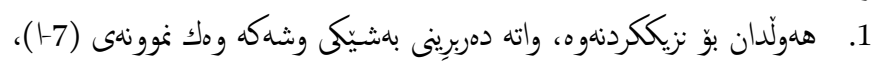
كه له بنهرِمتدا مهبهستى (7-

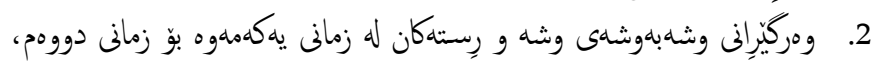
وهك نموونهى (8).

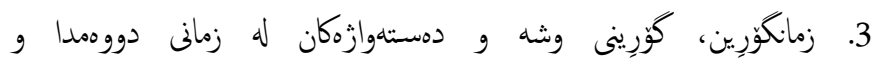

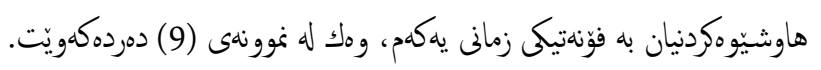

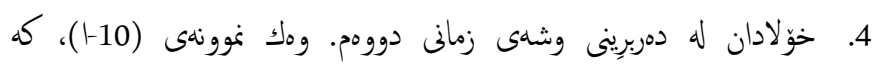

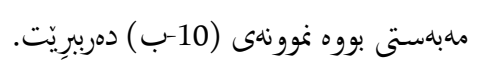

$$
\text { |) بوزّى /Pipe }
$$

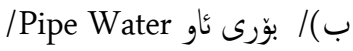

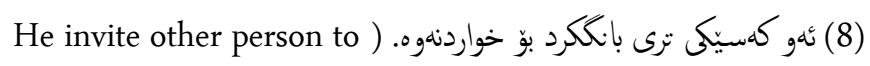
.(drink

$$
\begin{aligned}
& \text { | (Balon (بالَ / ( } \\
& \text { ب) /بالَوَن / البن }
\end{aligned}
$$

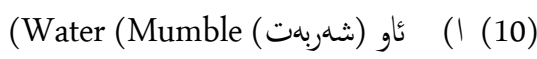

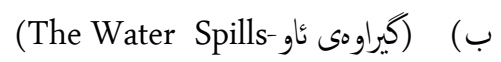

\section{2/3) شيّوازمكانى كون_تئكهلكردن:}

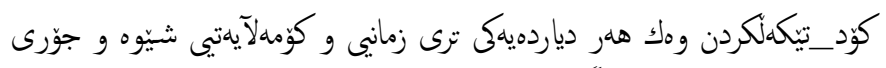

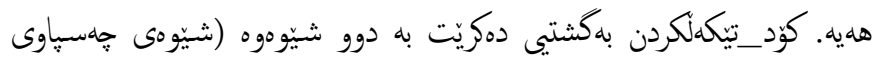

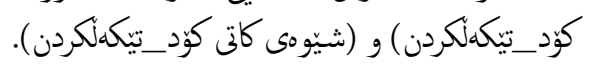

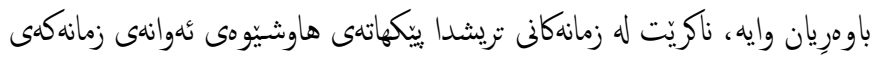

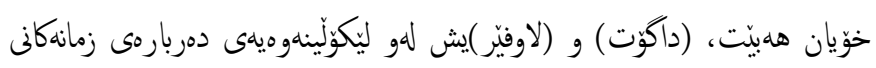

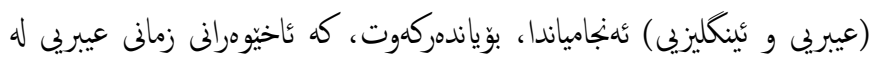

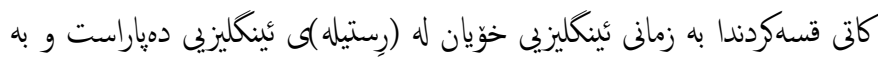

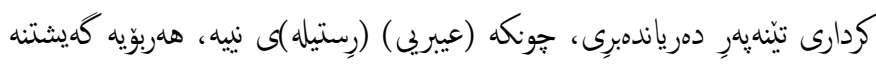

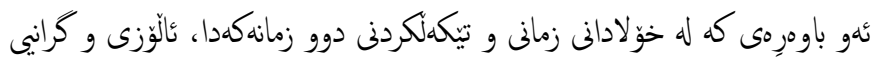

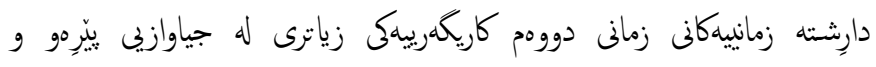

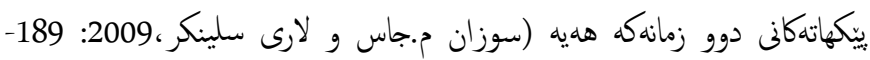

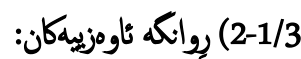

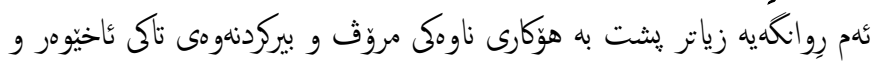

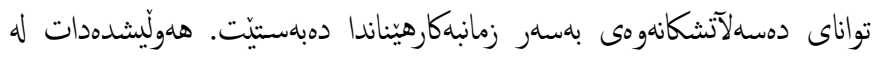

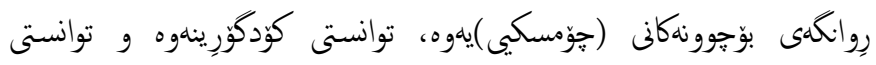

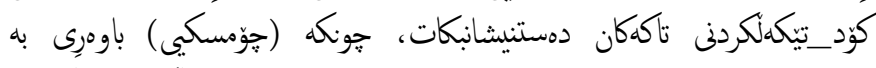

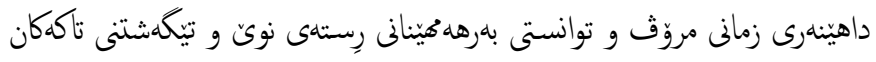

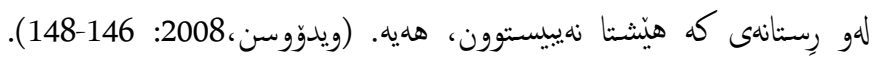

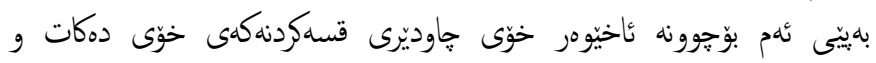

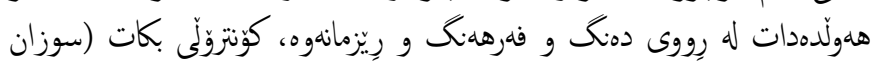

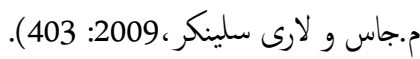

3-1/3 ريوانكه كوملآيهتييهكان:

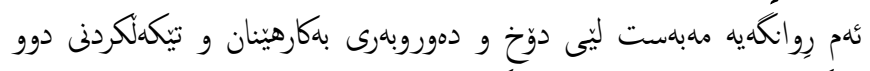

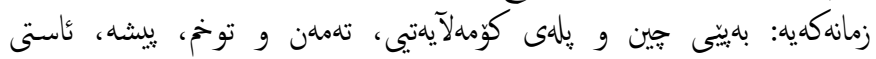

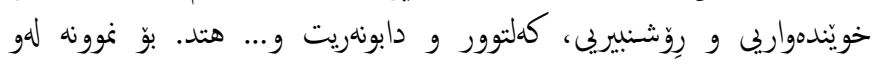

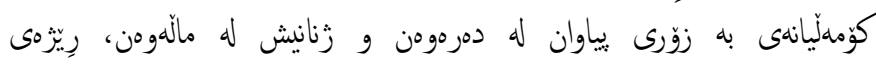

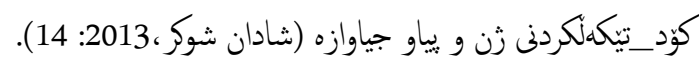

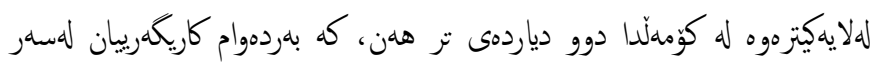

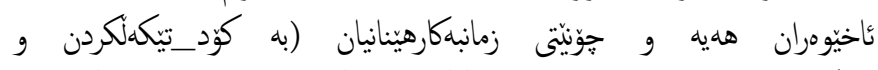

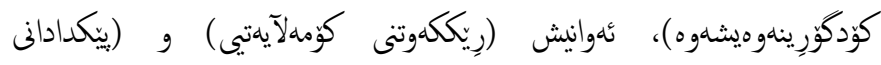

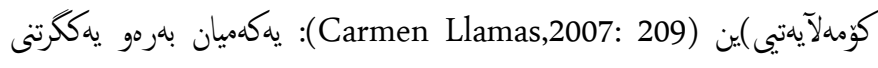

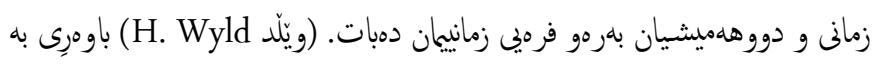

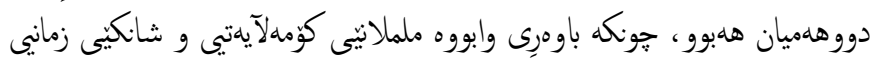

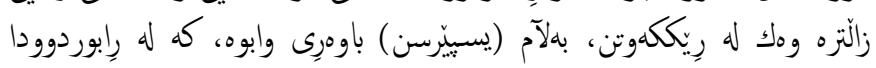

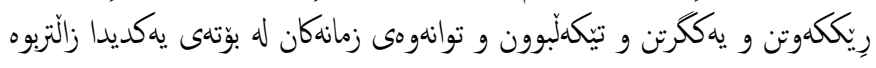

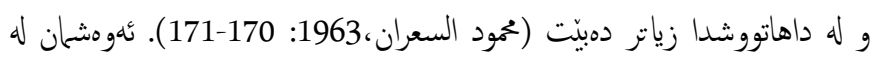

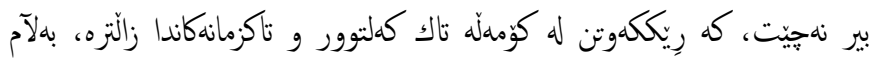

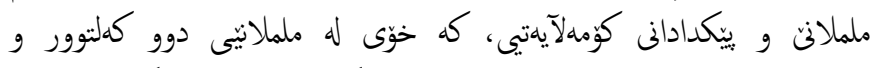

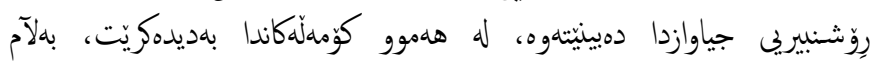

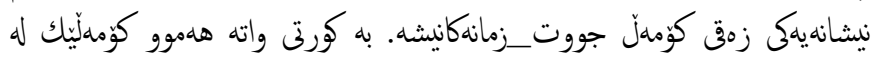

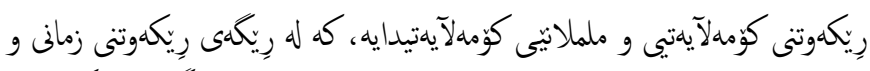

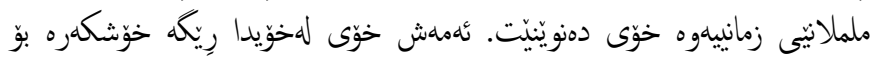
دياردهكانى كودونورِينهوه و كود_تيكهلكردن. 


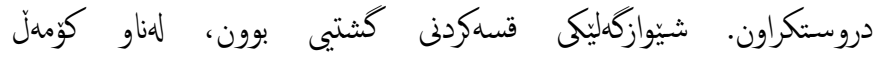

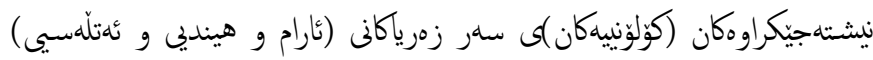

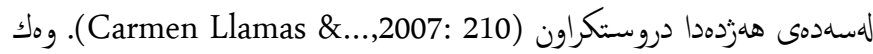

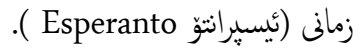

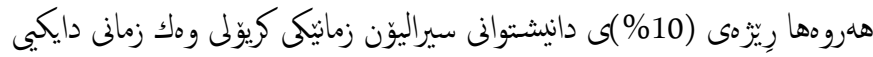

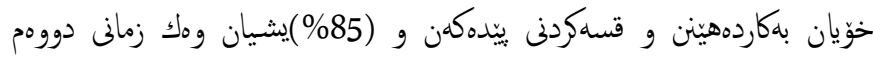

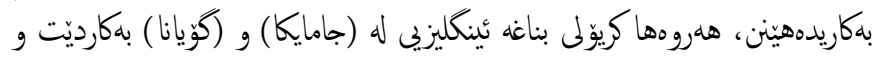

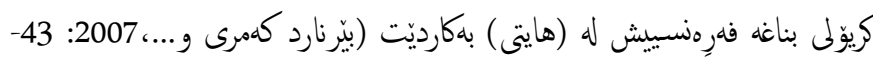

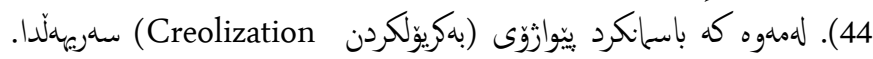

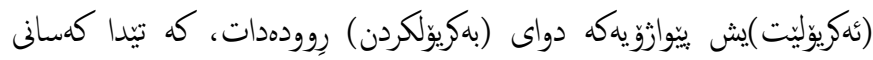

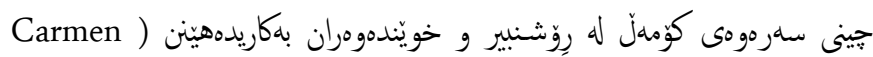
.(Llamas \&...,2007: 205

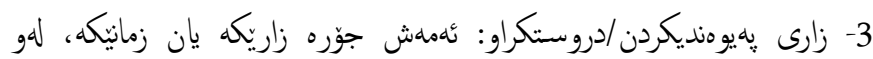

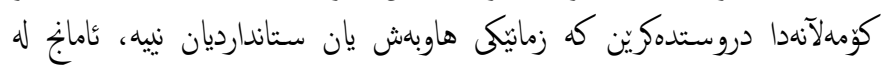

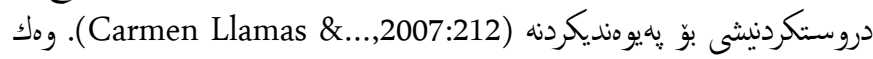

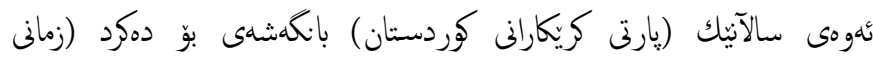

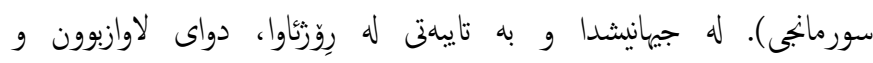

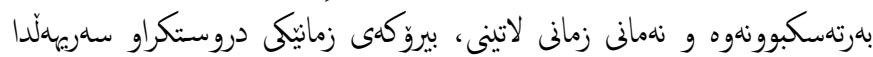

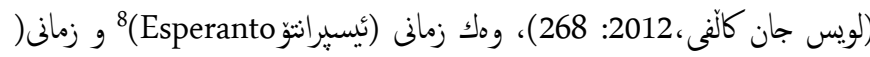

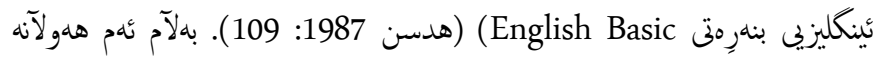
زورّينه رِهايان سهركموتو نهبوون.

\section{2-2/3) كود_تيكةلكردنى كاتيى/كسميى:}

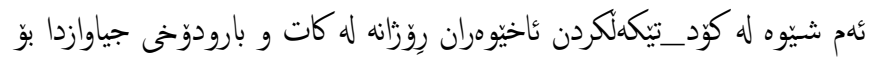

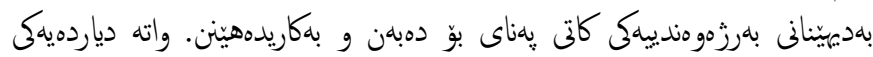

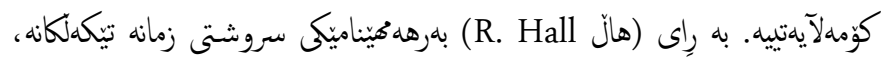

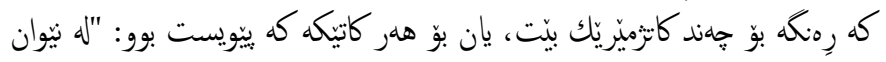

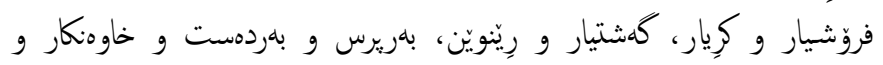

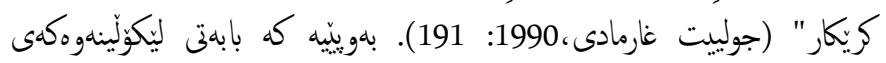

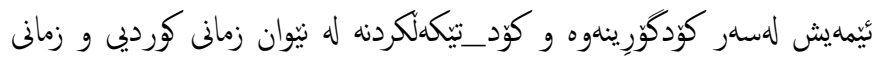

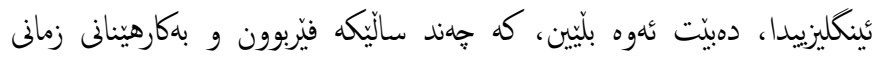

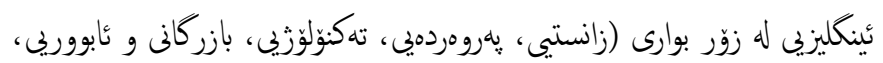

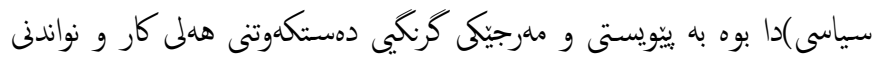

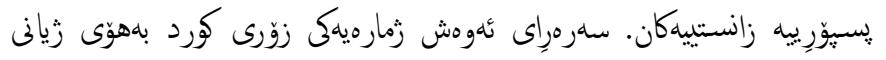

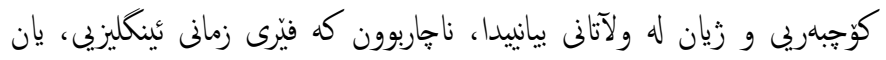

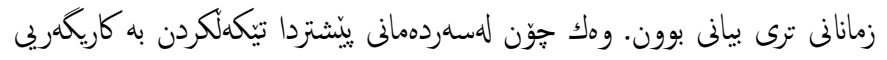

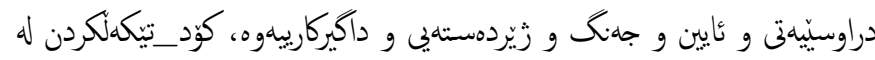

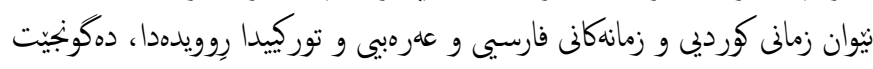

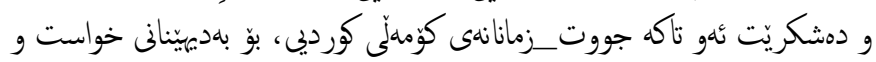

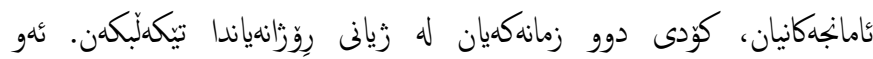

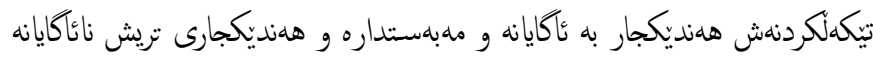

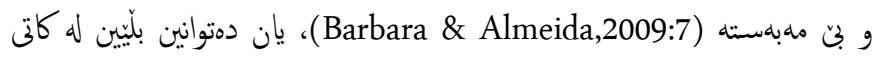

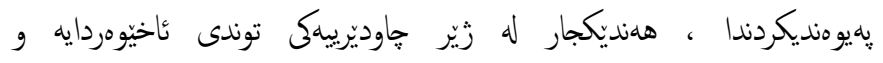

\section{1-2/3) شيّومى جهسباوى كود_تيكةلكردن/ كود_تيككلكردنى كوملآيهتيى:}

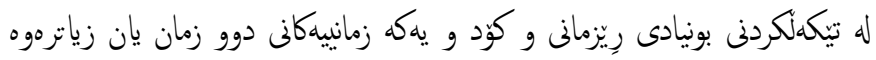

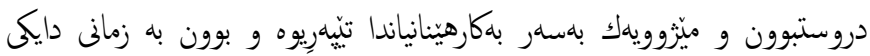

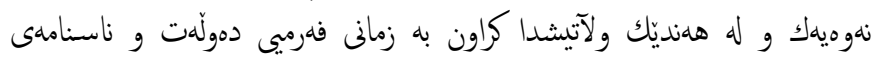

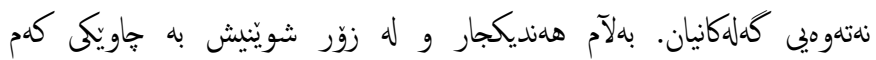

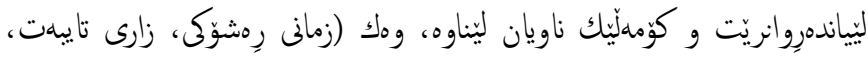

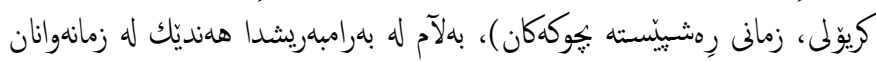

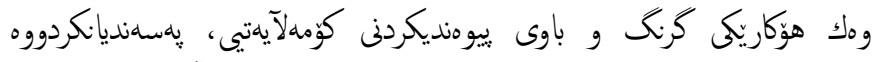

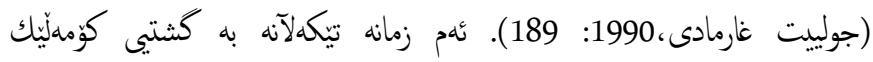

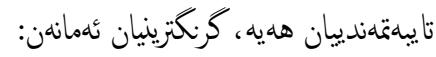

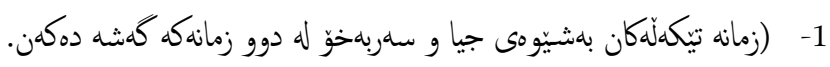

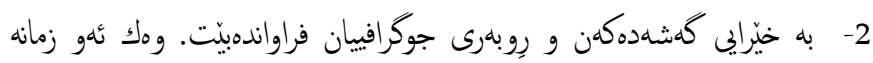

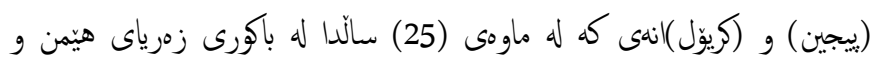

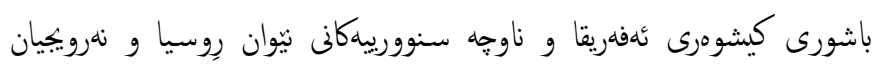
بلآوبوونهوه.

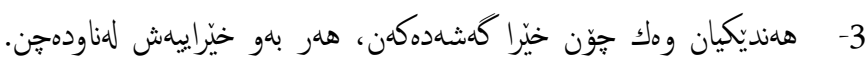

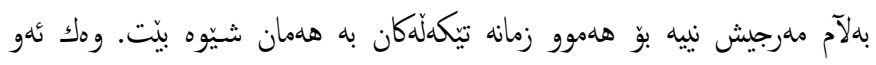

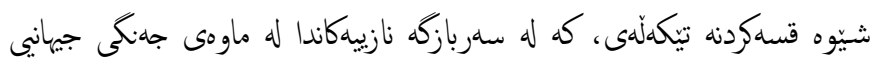

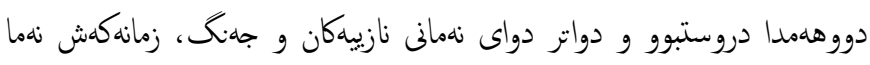
(جولييت غارمادى، 1990: 191-192)).

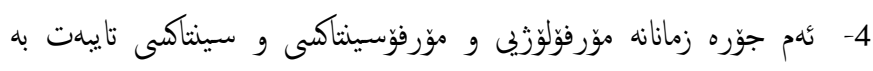

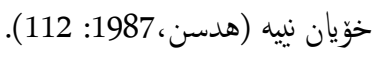

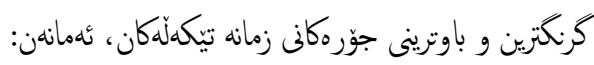

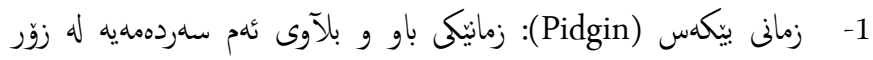

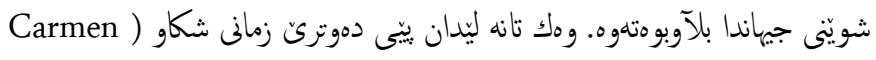
20 :Llamas \&...,2007) 20

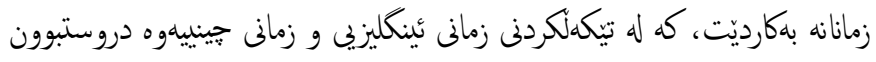

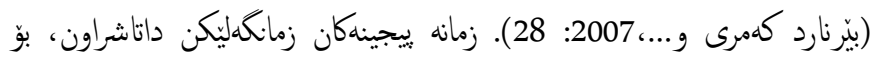

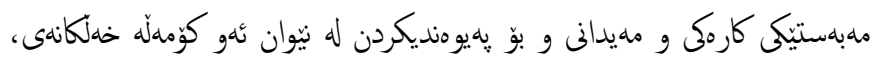

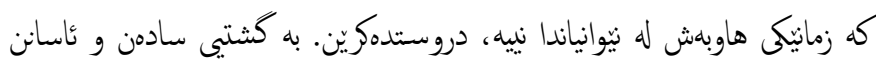

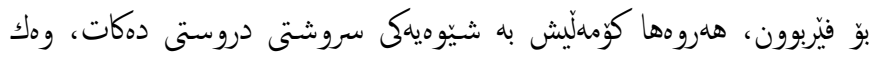

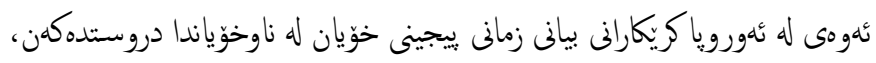

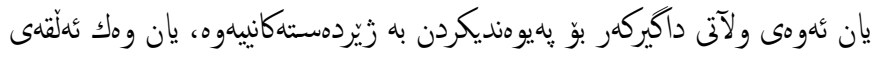

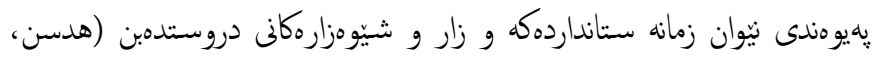

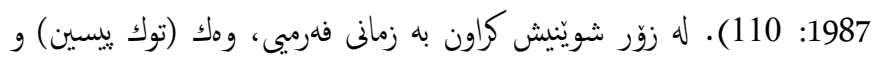

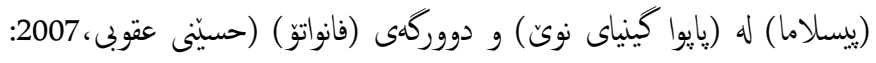

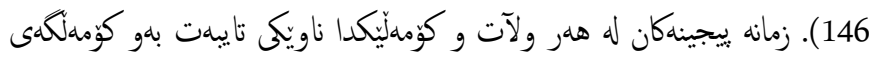
يه

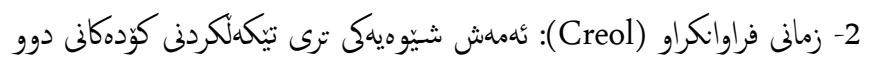

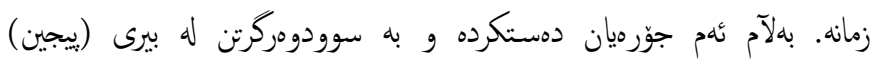




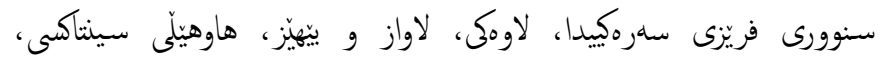
دووبارهبوونهوه. 3- كونجاندنى فهرهه:كيى: دياريكردن و جياكردنهوه و كونجاندنى كؤد و ينّكهاته

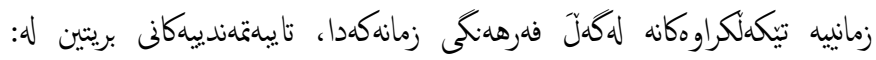

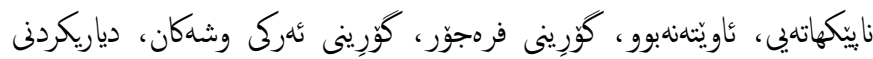

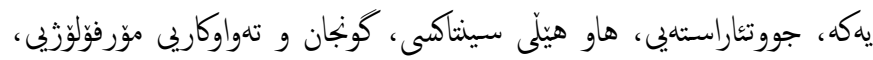

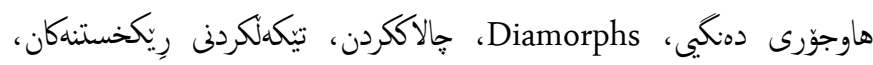
فرهياسايى.

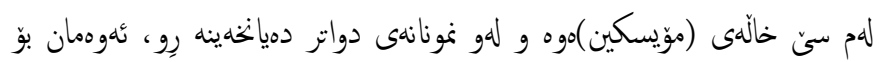

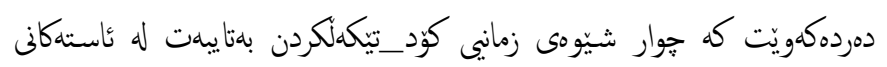
موّرفوّلوّزيى و سينتاكسدا هلن:

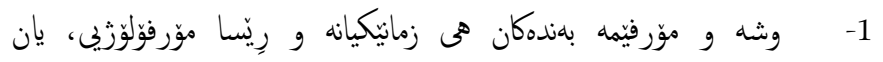
سينتاكسبيهكى هى زمانهكى تر.

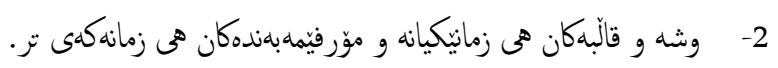

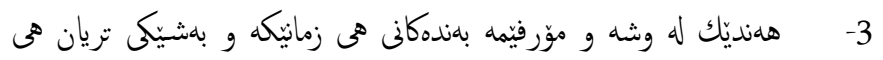
زمانهكى تزه.

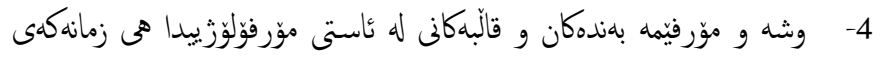
تره.

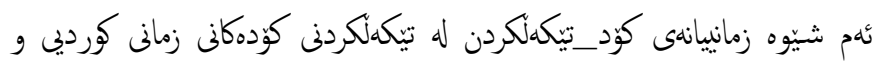

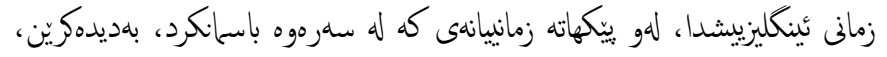

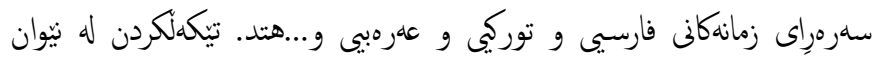

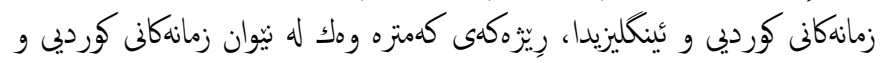

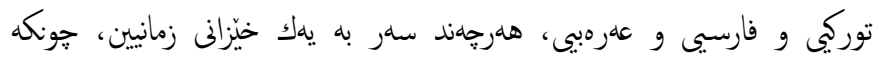

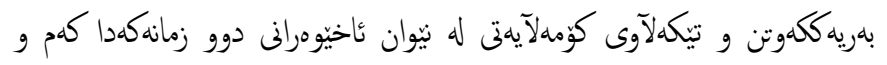

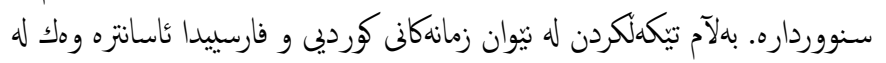

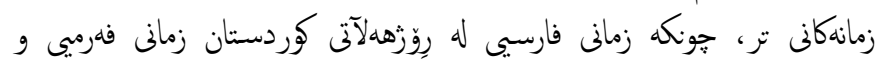

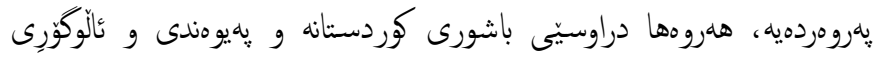

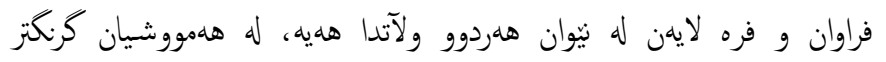

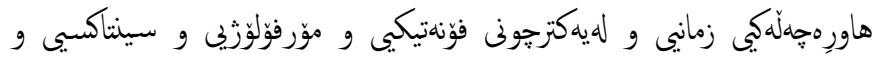
تهنانهت هاوبهشيى واتايشي له نئيوانياندا هليه.

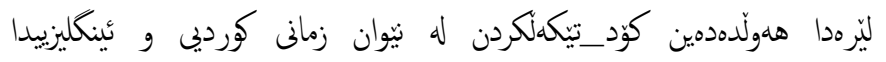

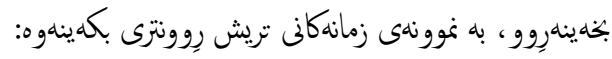

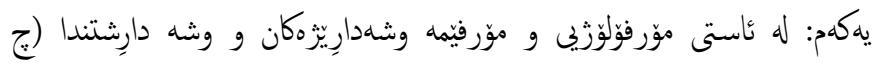

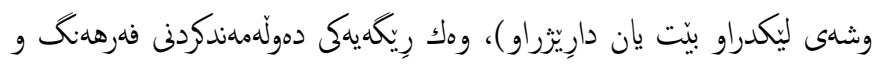

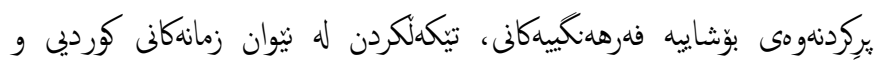

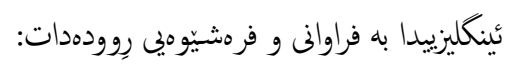

1- وشهى كورديى و قالّى ئينكليزيى'، وهك نموونهكانى (11).

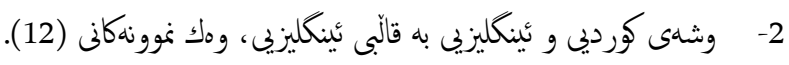

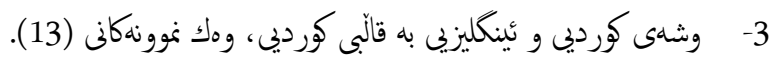

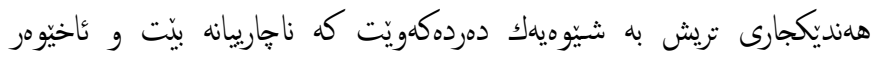
نهتوانيت خوّى ليّى لابدات (جولييت غارمادى، 1990: 182: 182).

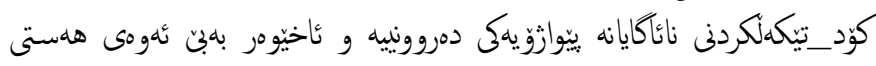

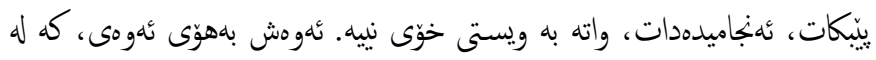

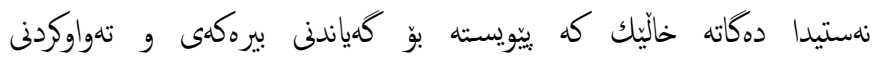

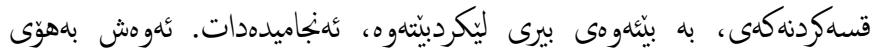

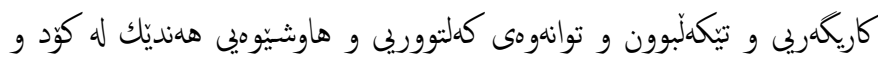

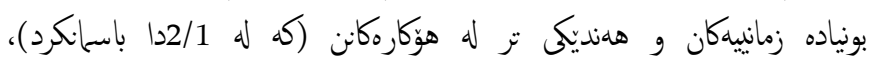

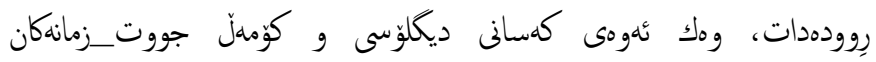
ئهنجاميدهدن.

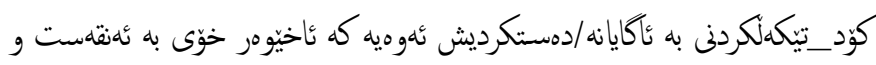

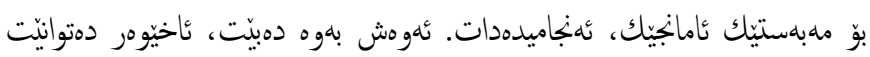

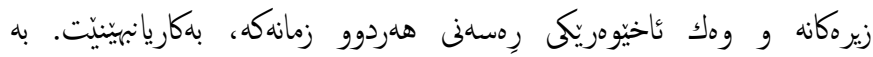

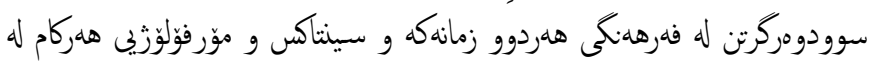

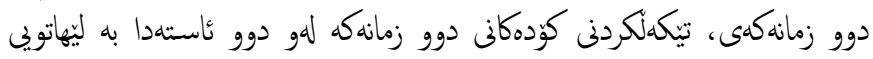

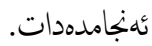

\section{3-3 ييكهاته زمانييةكانى كود_تيكهلكردن:}

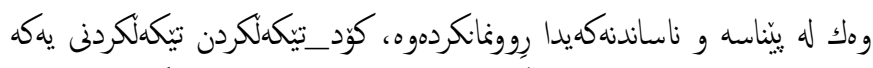

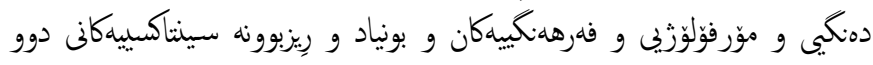

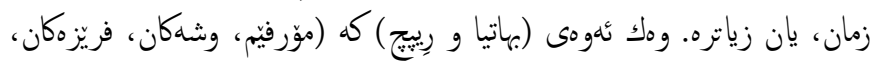

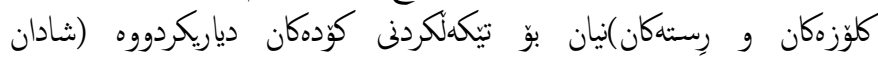
شوكر، 2008: 6كون ).

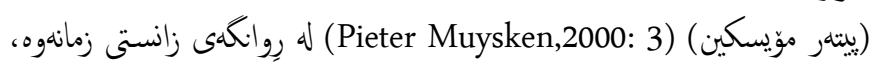

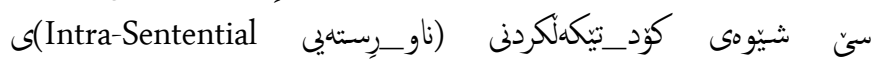

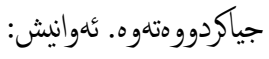

1- تئكردن: تيّكردنى يهكهى فهرههنكى (موّرفيّمه بهندهكان بيّت يان وشهكان)،

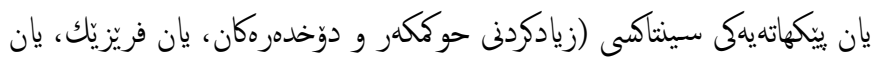

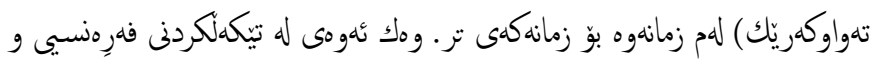

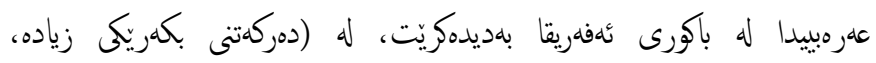

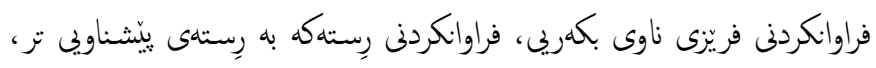

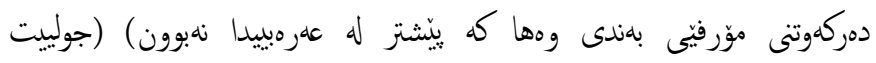

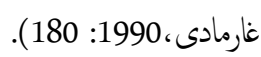

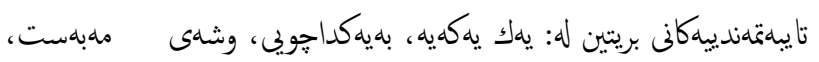

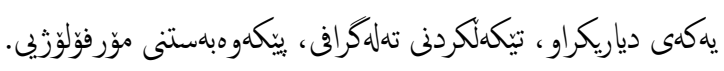

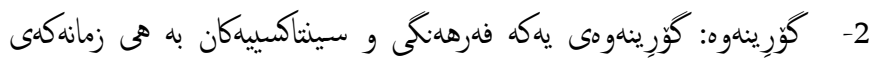

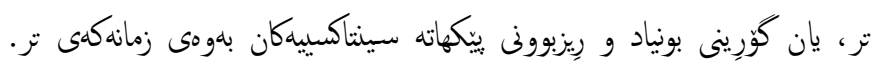

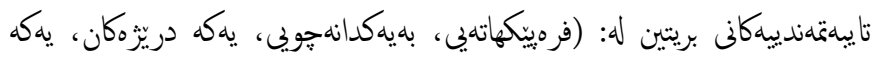

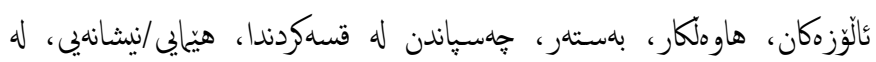


دابنيّن، بلآلم جياوازييكك لهومدايه كه له ئنكليزيبدا جيناوى لكاو نييه، بوّيه

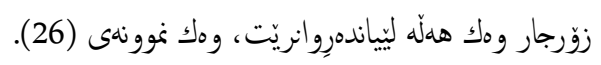

.You want to push the Pen (24

.Push pen -1

ب- Pen push. (سوزان م. جاس و لارى سلينكر، (سل، (194: 1909)

[Man[s] came[s. (26)

(كاروان عومهر قادر، 2014)، نموونهى (26) به هلّله و كشتناندنى فيرّخواز

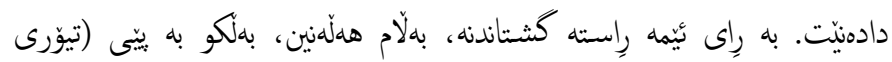

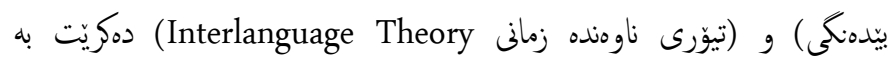

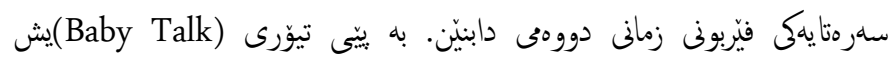

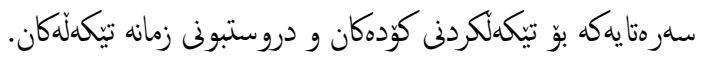

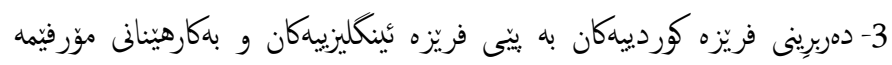

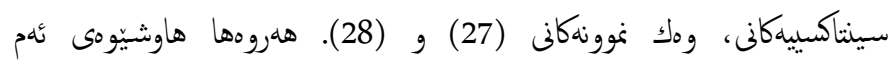

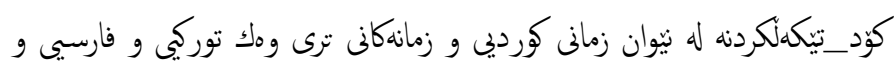

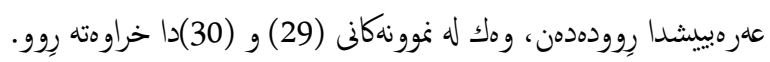

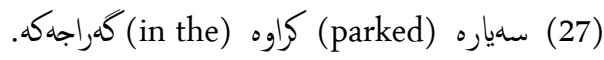

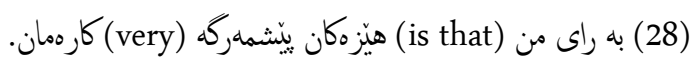

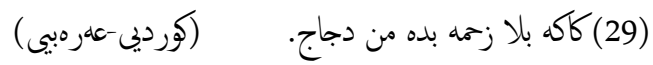
(30) ما ئثرينا و محهمديم، حهز به زمانى فارسى كزديم.

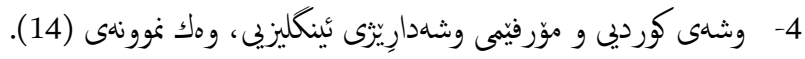

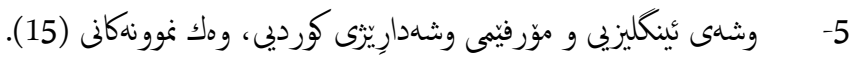

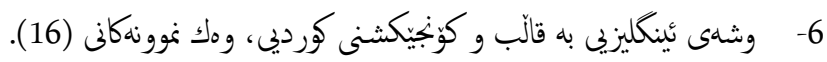

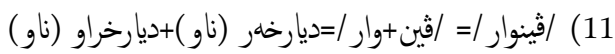

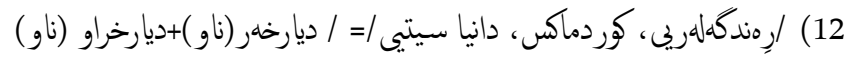

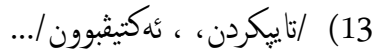
14) أيبهالهيشن/ (15)

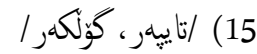
16) اكالاكسيى نوت، نَايفونى كوّلّد/...

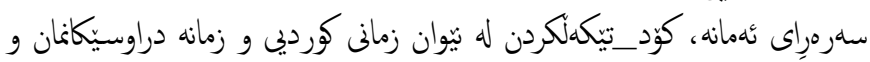

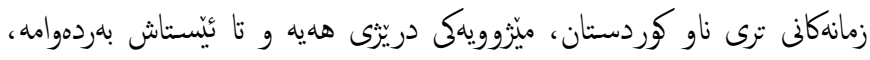

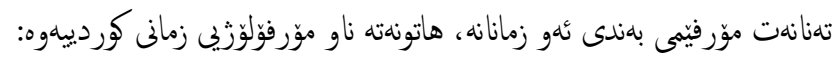

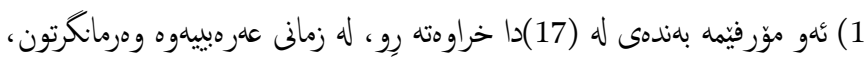

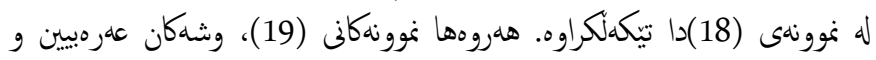
لاكر و بلستهرهانيان كورديين. ....0) (17)

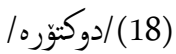
(19) / نارِازيى، علمهلييهى سياسيى، حهشدى شهعبي.../

2) موّرفئمه بهندهكانى وهك نموونهى (20)، توركين و له وشهكانى (21)دا

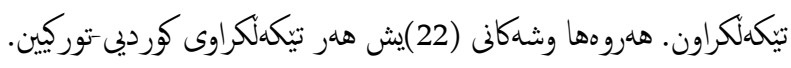

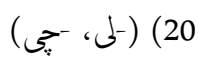

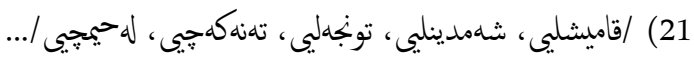

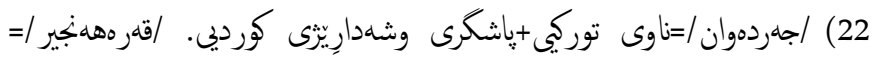

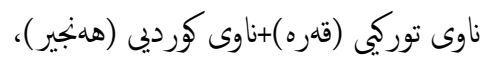

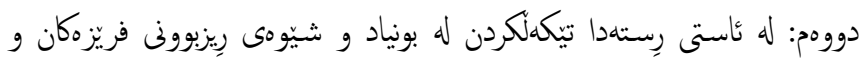

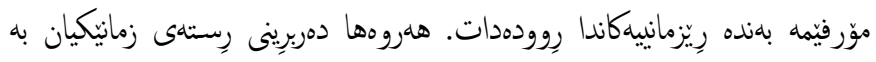

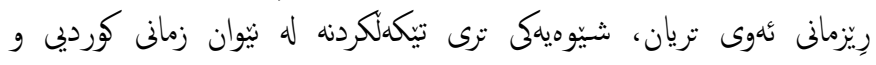

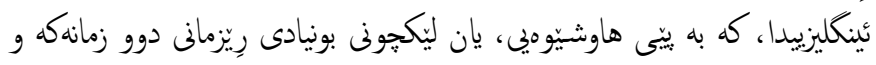

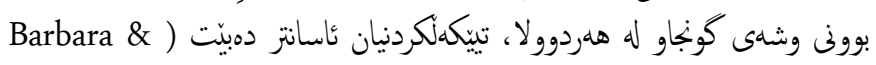

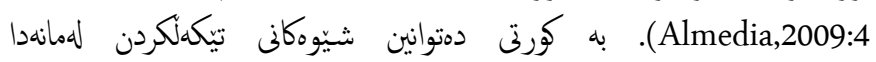
كورتبكهينهوه: - 1

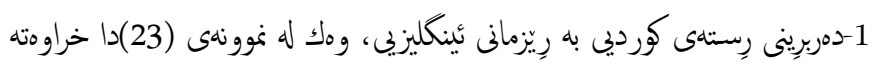

$$
\begin{aligned}
& \text { 23) - لهويّ جيت دهرد ؟ } \\
& \text { - من دمزنى يبانو. }
\end{aligned}
$$

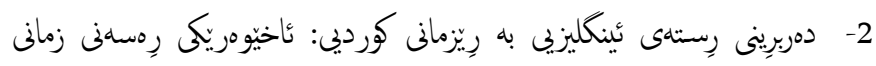

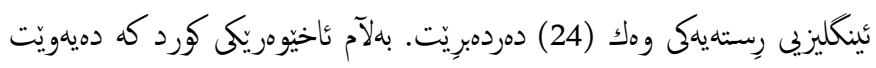

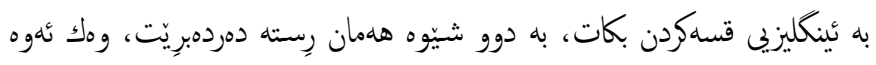

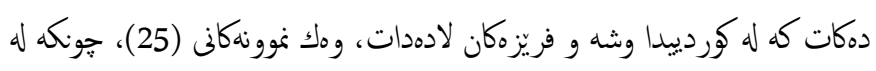

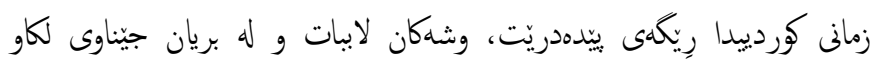




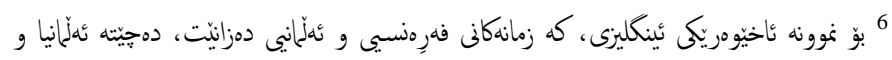

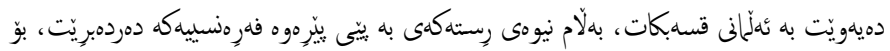

نمونه:

?Tu as mein Fax be commen

7 (س تيوزبيةكانى (1-1/3)، له (غارمادى)يهوه ومرمانكرتووه.

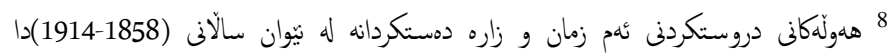

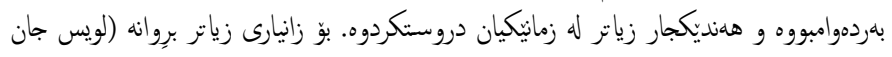
كالّفى،2012: 269-270).

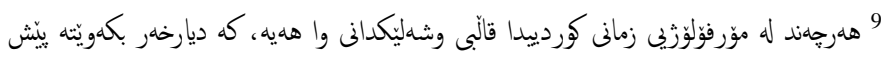

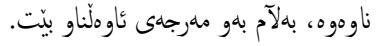

\section{سهرجاو0كان}

سلرجهاوه كوردييةكان:

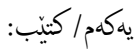

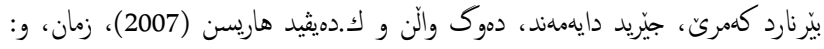

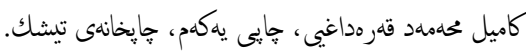

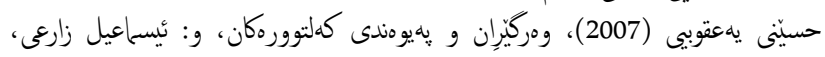

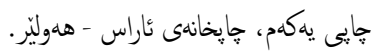

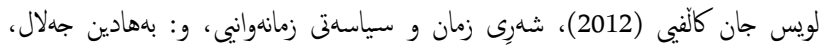

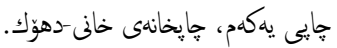

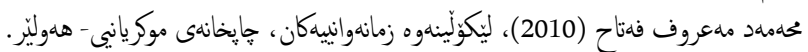

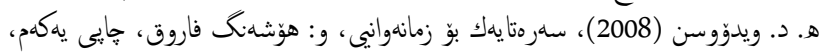
جإِخانهى خانى - دهوَك.

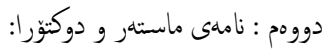
شادان شوكر (2008)، زمان تيكهلكردن له قسهردندا، (ماستهر)، كوليّزى زمان- زانكوىى سهلآحهددين.

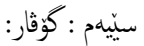

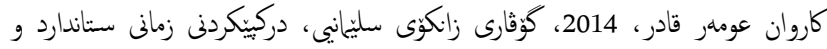

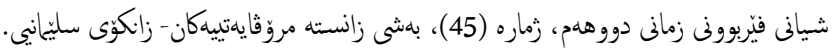
سهرجاوه فارسييةكان:

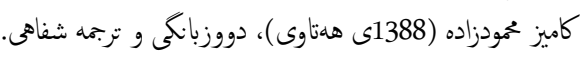

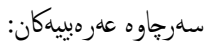

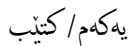
اندرية مارتينى (2009)، وظيفة الكالسن و ديناميتها، ت: نادر سراج، الطبعة الوولى،

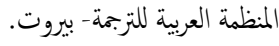
برتيل مالبرج (2010)، مدخل الى اللسانيات، ت: سيد عبدالظاهر ، الطبعة الاولى، المركز القوى للتزبمة-القاهرة. جان بيرو (2001)، اللسانيات، ت: الحواس مسعودى و مفتاح بن عروس، دار الحار اللآفاق.

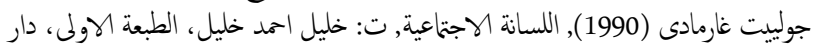

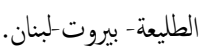

\section{ثنبجام}

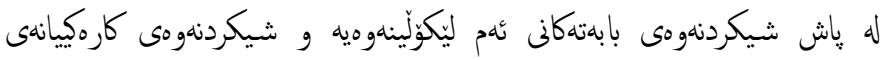

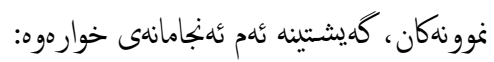

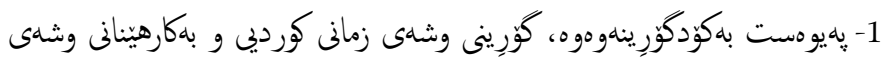

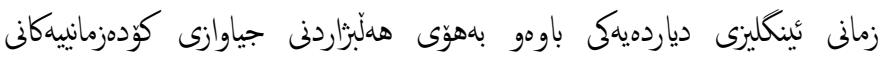
هلمدووزمانهكةوه رِوودمدات.

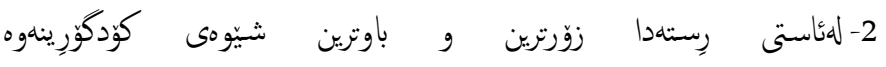

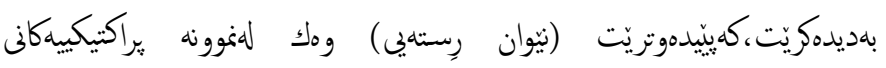
تويَّينهوهكمدا هاتووه.

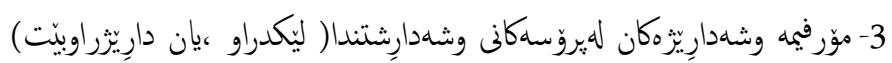

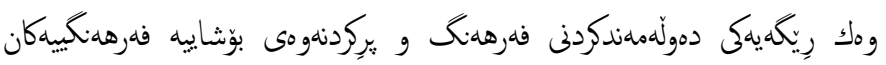

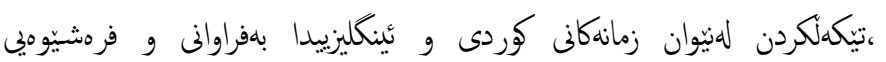

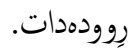

4- لهئاستى رِسته تيكهلكردن لهبونياد و شيّوهى رِيزبوونى فريّزهكان و موّرفيمه بهنده

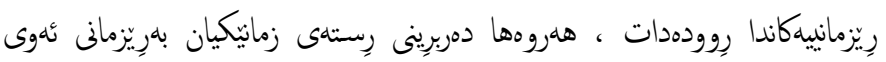
تريان ،شيّوميهك ترى تيكهلكردنه لهينوان زمانى كوردى و ئينكليزيدا.

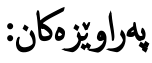

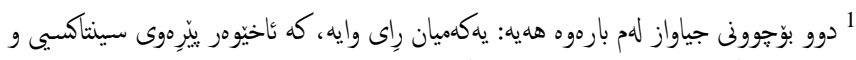

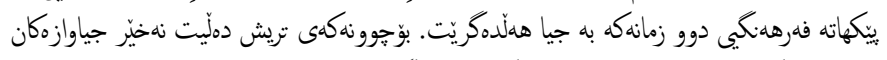

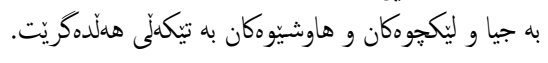

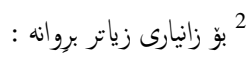

Barbara E. Bullock and Almeida Jacqueline Toribio (2009), The Cambridge Handbook of Linguistic Code-switching, Cambridge University Press, www.cambridge.org.

3ُ بوّ زانيارى زياتر بروانه:

Pieter Muysken (2000), Bilingual Speech (A Typology of CodeMixing), First published, Cambridge University Press United Kingdom.

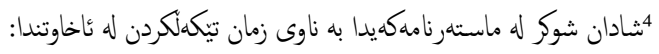

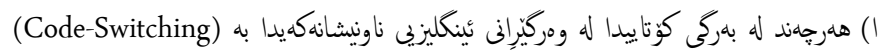

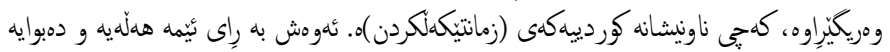

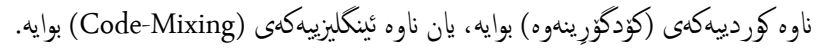

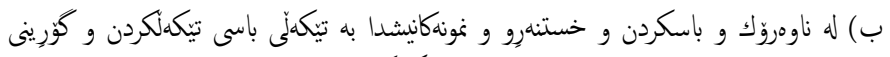

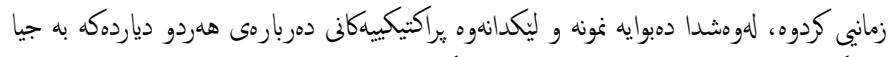

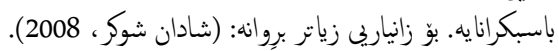

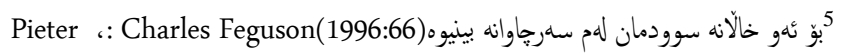

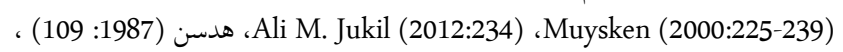

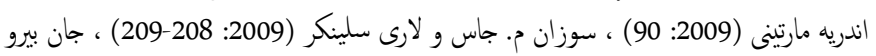

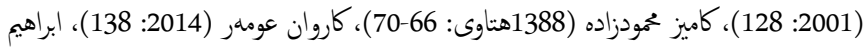

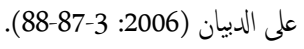




$$
\begin{aligned}
& \text { دانيال تشاندلر (2008)، أسس السيميائية، ت: طلال وهبه، الطبعة الاولى، بيروت - } \\
& \text { سوزان م. جاس و لارى سلينكر (2009)، اكتساب اللغة الثانية، (الجزء الاول)، ت: } \\
& \text { ماجد الممد، جامعة الملك سعود-السعودية. } \\
& \text { محمود السعران (1963)، اللغة و الجمتمع (رأى و منهج)، الطبعة الثانية، الأسكندرية-مصر. } \\
& \text { هادى نهر (1988)، علم اللغة الاجتماعى عند العرب، الطبعة الاولى، الجامعة المستنصرية. }
\end{aligned}
$$

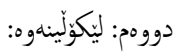

$$
\begin{aligned}
& \text { ابراهيم بن على الدبيان (2006 / 1427هجرى)، الصراع اللغوى، قسم علم اللغة والدراسات } \\
& \text { السامية و الشرقية-كلية دارالعلوم-جامعة القاهرة. } \\
& \text { لطفى بوقربة، محاضرات فى اللسانيات التطبيقية، جامعة البشار -معهد الادب واللغة- الجزائر. }
\end{aligned}
$$

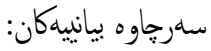

Ali M. Jukil (2012), Motivations of Code-Switching in the Classrooms of the Department of English(200) بجلة (الاستاذ)، العدد.

Barbara E. Bullock and Almeida Jacqueline Toribio (2009), The Cambridge Handbook of Linguistic Code-switching, Cambridge University Press, www.cambridge.org.

Carmen Llamas, Louise Mullany, and Peter Stockwell (2007), the Routledge Companion to Sociolinguistic, London and New York...

Muayad Juma An-Nasralla (2012), The Advisability of Using English-Arabic Code Switching as a Teaching Strategy in EFL University Classroom: A Case Study, مجلة (الاستاذ)، العدد (201) .

Pieter Muysken (2000), Bilingual Speech (A Typology of CodeMixing), First published, Cambridge University Press-United Kingdom. 